This article has been accepted for publication in Environmental Science and Technology (Published by ASC) and should be cited as:

Nawras Ghanem, Claire E. Stanley, Hauke Harms, Antonis Chatzinotas, Lukas Y. Wick. 2019. Mycelial effects on phage retention during transport in a microfluidic platform. Envrionmental Science and Technology, 53: 11755-11763.

First Published: 18 September 2019 https://doi.org/10.1021/acs.est.9b03502 


\section{Mycelial Effects on Phage Retention During Transport in a}

\section{Microfluidic Platform}

4 Nawras Ghanem ${ }^{1}$, Claire E. Stanley ${ }^{2}$, Hauke Harms ${ }^{1,3}$, Antonis Chatzinotas ${ }^{1,3}$ and Lukas Y. Wick ${ }^{1 *}$

$8{ }^{1}$ Helmholtz Centre for Environmental Research - UFZ, Department of Environmental Microbiology, 9 Permoserstraße 15, 04318 Leipzig, Germany.

$10{ }^{2}$ Agroecology and Environment Research Division, Agroscope, Reckenholzstrasse 191, 8046 Zurich, 11 Switzerland

$12{ }^{3}$ German Centre for Integrative Biodiversity Research (iDiv) Halle-Jena-Leipzig, Deutscher Platz 5e, 1304103 Leipzig, Germany

18 Running title: Transport of tracer phages along mycelia

21 Intended for: Environmental Science and Technology

26 * Corresponding author: Helmholtz Centre for Environmental Research - UFZ. Department of 27 Environmental Microbiology; Permoserstrasse 15; 04318 Leipzig, Germany. Phone: +49 341235 28 1316, fax: +49 34123545 1316, e-mail: lukas.wick@ufz.de. 


\section{AbSTRACT}

30 Phages (i.e. viruses that infect bacteria) have been considered as good tracers for the hydrological 31 transport of colloids and (pathogenic) viruses. Little, however, is known about interactions of phages

32 with (fungal) mycelia as the prevalent soil microbial biomass. Forming extensive and dense networks, 33 mycelia provide significant surfaces for phage-hyphal interactions. Here, we for the first time 34 quantified the mycelial retention of phages in a microfluidic platform that allowed for defined fluid 35 exchange around hyphae. Two common lytic tracer phages (Escherichia coli phage T4 and marine 36 phage PSA-HS2) and two mycelia of differing surface properties (Coprionopsis cinerea, Pythium 37 ultimum) were employed. Phage-hyphal interaction energies were approximated by the extended 38 Derjaguin-Landau-Verwey-Overbeek (XDLVO) approach of colloidal interaction. Our data show 39 initial hyphal retention of phages of up to $\approx 4 \times 10^{7} \mathrm{PFU} \mathrm{mm} \mathrm{m}^{-2}\left(\approx 2550 \mathrm{PFU} \mathrm{mm}^{-2} \mathrm{~s}^{-1}\right)$ with a retention 40 efficiency depending on the hyphal and, to a lesser extent, the phage surface properties. Experimental 41 data were supported by XDLVO calculations, which revealed the highest attractive forces for the 42 interaction between hydrophobic T4 phages and hydrophobic C. cinerea surfaces. Our data suggest 43 that mycelia may be relevant for the retention of phages in the subsurface and need to be considered 44 in subsurface phage tracer studies. Mycelia-phage interactions may further be exploited for the 45 development of novel strategies to reduce or hinder the transport of undesirable (bio-)colloidal entities in 46 environmental filter-systems.

KEYWORDS: marine phages, tracer, hyphae, microfluidic platform, transport, mycelia 
59 TOC / ABSTract ART

60

61

62

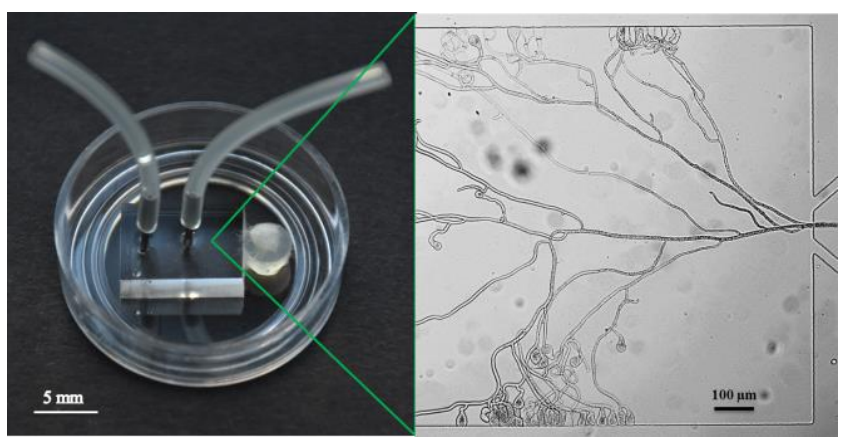

63

64

65 
67 Previous work has highlighted the relevance of phages (i.e. viruses that infect bacteria) ${ }^{1,2}$ as promising 68 tracers for fecal contamination or for the evaluation of colloidal and water transport. ${ }^{3,4,5}$ Although

69 phage tracers have significantly improved our understanding of water and colloid movement in 70 aquifers $^{6}$, information on the transport of phage tracers in the complex soil subsurface is still limited, 71 yet highly needed. For example, accurate descriptions of microbial (colloid) transport and soil-related 72 transport drivers are needed to assess the risk of pathogen contamination to drinking water supplies or 73 to develop control strategies and treatment options. Although still rarely applied, marine tracer phages

74 hold much promise as tracers in subsurface ecosystems, as they and their hosts are absent in terrestrial 75 ecosystems. Typically, up to $10^{15}$ phages $(\sim 1 \mathrm{~g})$ can be applied and phage concentrations of $<10$ 76 phages $\mathrm{mL}^{-1}$ of recovered water can be detected ${ }^{7}$ by specific interactions with their host bacteria using 77 plaque forming unit (PFU) assays. ${ }^{7,8,9,10}$ Subsurface transport of phages (and other viruses) is driven 78 by environmental factors, phage type and phage interaction with autochthonous soil microorganisms. ${ }^{11}$ 79 Environmental factors included soil type and texture, ${ }^{12,13,14,15}$ electrolyte composition ${ }^{16,17}$ or the degree 80 of water saturation in soil. ${ }^{11,18,19}$ Other research assessed the influence of virus characteristics such as 81 the effect of the isoelectric point, ${ }^{20}$ combinations of size and isoelectric point ${ }^{21}$ or the morphology of 82 phages and other viruses. ${ }^{22}$ While abiotic environmental drivers have been widely studied, insufficient 83 knowledge exists concerning interactions of phages and viruses with non-host microbes (termed in the 84 following as unspecific phage-microbe interactions). Such interactions may be of high importance for 85 the transport and survival of pathogens in soil and the upper layer of the Earth's Critical Zone $(\mathrm{CZ})^{23}$, 86 i.e. the thin, living and permeable layer that connects the atmosphere with the geosphere. Research on 87 unspecific phage-microbe interactions mainly evaluated the influence of sterile vs. non-sterile 88 conditions on the fate of phages. ${ }^{24}$ These studies suggest better survival of phages and other viruses in 89 sterile rather than in non-sterile environments. ${ }^{24,25,26}$ Other studies have highlighted the role of fungi 90 as mediators for the virulence of plant viruses. ${ }^{27,28,29}$ To our knowledge, however, no literature exists 
91 on unspecific interactions of phages with hyphal surfaces or the effect of (fungal) mycelia on

92 waterborne transport of phages.

93 Fungi occur in nearly every aerobic habitat, being important drivers of biogeochemical cycles ${ }^{30,31}$ and

94 fertility of soils. Being the major microbial biomass in soil, they typically develop a spatially extensive 95 mycelium, which comprises up to $1000 \mathrm{~m}$ of hyphae per gram of dried soil. ${ }^{32,33}$ Mycelia also provide 96 ideal 'logistic networks' for bacterial evolution ${ }^{34,35,36}$ as well as the transport of bacteria. Fungal growth 97 is not restricted to saturated environments, as their hyphae are also able to breach air-water interfaces ${ }^{37}$ 98 and thereby connect different soil microenvironments. ${ }^{32}$ Of central importance for possible phage 99 transport is the observation that hyphae may change the physico-chemical properties of their surface ${ }^{38}$ 100 and hence, alter the water infiltration properties of soils through the production of large amounts of 101 hydrophobic compounds in the outer cell wall. ${ }^{39}$

102 Here, we hypothesized that mycelia might retain phages, due to the physico-chemical interactions of 103 phages with hyphal surfaces, and hence would influence waterborne phage transport. Using a well104 controlled microfluidic platform, we quantified the effects of mycelia on phage retention and transport 105 at the micrometer scale. The microfluidic platform allowed single hyphae to be subjected to a defined 106 concentration of phages and to quantify their interactions by comparing the in- and outflow 107 concentrations of phages. Two lytic phages commonly used as tracers to follow pathogen 108 contamination (E. coli T4 phage) or colloidal particle transport ${ }^{22}$ (marine phage PSA-HS2) were used 109 as models. The phages belong to different virus families ${ }^{40,41}$ and vary in their morphology and physico110 chemical surface properties. Two filamentous soil organisms (Coprinopsis cinerea and Pythium 111 ultimum) of varying surface hydrophobicity were also implemented. Experimental observations were 112 accompanied by the extended Derjaguin-Landau-Verwey-Overbeek approach (XDLVO) of colloidal 113 interaction that describes the forces between charged surfaces interacting in a liquid medium. Our 114 findings suggest that the mycosphere may significantly influence the transport and fate of phages and 115 phage tracers. 
MATERIALS AND METHODS

\section{Organisms and culture conditions}

119 Two well-characterized lytic tracer phages were studied (Table 1). The T4 coliphage (T4) ${ }^{42}$ and its 120 host E. coli (Migula 1895) ${ }^{43}$ were purchased from Deutsche Sammlung von Mikroorganismen und 121 Zellkulturen GmbH (DSMZ, Germany), while the marine phage PSA-HS2 and its host strain 122 Pseudoalteromonas H13-15 were kindly provided by Dr. B. M. Duhaime (University of Michigan, 123 USA). ${ }^{44}$ The T4 coliphage (Myoviridae) and the PSA-HS2 (Siphoviridae) are of different morphology. 124 Both phages were propagated, purified and counted as described previously. ${ }^{22} P$. H13-15 and E. coli 125 were grown at room temperature using dilute (50\%) $2216 \mathrm{E}$ medium ${ }^{45}$ and Luria-Bertani (LB) 126 medium $^{46}$. Both phages were stored in $\mathrm{SM}$ buffer $\left(100 \mathrm{mM} \mathrm{NaCl}, 8 \mathrm{mM} \mathrm{MgSO} 47 \mathrm{H}_{2} \mathrm{O}, 50 \mathrm{mM}\right.$ Tris127 HCl. $\mathrm{pH}$ 7). Phages were quantified by a modified spotting plaque assay technique ${ }^{22}$ by incubating 128 phage host pairs overnight either at room temperature (RT, $\left.25^{\circ} \mathrm{C}\right)$ (PSA-HS2) or at $37^{\circ} \mathrm{C}(\mathrm{T} 4$ 129 coliphage). The agaricomycete $C$. cinerea strain AmutBmut pMA412 (C. cinerea) and the oomycete $130 P$. ultimum $^{32}$ exhibit hyphal surfaces of varying hydrophobicity. ${ }^{38}$ C. cinerea strain AmutBmut 131 pMA412 constitutively expresses the red fluorescent protein dTomato ${ }^{47}$ C. cinerea and $P$. ultimum 132 were cultivated on yeast-malt extract-glucose medium solidified with agar (YMG, Table S2) and Luria 133 Bertani (LB) agar for three days at $30{ }^{\circ} \mathrm{C}$ and RT, respectively. ${ }^{47,48}$

\section{Stability and viability of phage suspensions}

135 Conditioned (i.e., cell-free) media were prepared by cultivating $C$. cinerea and $P$. ultimum in glucose136 based liquid CCMM minimal ${ }^{47}$ (Table S2) and LB media using a shaker incubator (SM-30, Edmund 137 Bühler $\mathrm{GmbH}$, Bodelshausen, Germany) at $150 \mathrm{rpm}$, at $30{ }^{\circ} \mathrm{C}$ for $9 \mathrm{~d}$. Conditioned media were 138 obtained by vacuum filtration of the mycelial suspensions using a glass frit (Schott pore 40, DURAN® 139 filter funnel, DWK Life Sciences, Wertheim, Germany) and subsequently stored at $4{ }^{\circ} \mathrm{C}$. The stability 140 (i.e. phage aggregation and infectivity) of phage suspensions was investigated in batch experiments at 
141 RT in $10 \mathrm{~mL}$ glass vials ${ }^{49}$ containing $6 \mathrm{~mL}$ of phage suspensions $\left(10^{8}-10^{9} \mathrm{PFU} \mathrm{mL} \mathrm{m}^{-1}\right)$ in conditioned 142 media (Fig. S1). Experiments were performed in triplicate by exposing phages to the conditioned

143 media for 0,4 and $22 \mathrm{~h}$ and subsequently performing a PFU quantification (Fig. S1). The stability of 144 the phage suspensions was calculated as the ratios of phage concentrations (Table 2). Similar 145 experiments were performed using fresh media as controls (Fig. S2).

\section{Characterization of physico-chemical surface properties}

148 The contact angles of water $\theta_{\mathrm{w}}$, formamide $\theta_{\mathrm{f}}$, and methylene iodide $\theta_{\mathrm{mi}}$ were measured using a DSA 149100 drop-shape analysis system (Krüss GmbH, Hamburg, Germany). Briefly, mycelia of the organisms 150 were cultivated for 2 - 3 days on a $0.45 \mu \mathrm{m}$-filter (NC 45, Cellulose Nitrate Membrane Whatman, 151 Maidstone, Kent, United Kingdom) placed on the surface of LB (P. ultimum) or YMG agar plate $(C$. 152 cinerea). Filters covered with fungi were removed and mounted on a microscope slide and the contact 153 angles measured as detailed elsewhere. ${ }^{38,50}$ The zeta-potential $(\zeta)$ for the mycelia of $C$. cinerea and $P$. 154 ultimum were approximated from the electrophoretic mobility of hyphal elements measured by 155 Doppler electrophoretic light scattering analysis (Zetamaster, Malvern Instruments, Malvern, UK). 156 Mycelia of both organisms were cultivated for 3 days as described above. The biomass was then 157 carefully scratched off the filter using a sterile spatula, suspended in $1 \mathrm{~mL}$ of SM buffer $(100 \mathrm{mM}, \mathrm{pH}$ $158=7)$ and homogenized using a micro-blender according to Potter-Elvehjem (Carl Roth GmbH $+\mathrm{Co}$, 159 Germany) prior to zeta potential measurement. The zeta potential of PSA-HS2 and T4 phage 160 suspensions ( $\mathrm{SM}$ buffer; $100 \mathrm{mM}, \mathrm{pH}=7$ ) was approximated as described earlier. ${ }^{22}$

\section{Phage transport experiments}

163 Microfluidic device design and preparation 
164 Microfluidic devices were prepared as described in Stanley et al. ${ }^{47}$ based on a channel architecture ${ }^{51}$ 165 that enables laminar flow conditions as a result of actively pumping solutions into the observation 166 chamber (Figs. $1 \&$ S3; cf. SI for detailed description).

\section{Incubation and visualization of mycelial growth structures}

Using a syringe (Injekt®Solo, $2 \mathrm{~mL}, \mathrm{~B}$. Braun, Melsungen, Germany), the microfluidic devices were filled with either liquid LB medium for P. ultimum or glucose-based CCMM for $C$. cinerea. A small agar plug $\left(\approx 6 \mathrm{~mm}^{2}\right)$ containing the fungal inoculum was placed next to the opening of the microfluidic channel (Fig. 1). The microfluidic devices were incubated for $24 \mathrm{~h}(P$. ultimum) and $48 \mathrm{~h}(C$. cinerea) in a humid and dark environment to allow the mycelia to reach the end of the observation channel. Prior to the addition of the phages, the mycelial structure in the observation channel was determined using an AZ100M fluorescence microscope (Nikon, Düsseldorf, Germany) and Nikon NIS-Elements software. The surface area of the mycelia in the observation chamber $\left(A_{\text {mycelia }}\right)$ was approximated based on the total length of the mycelia in the observation chamber assuming hyphae to be tubes having a diameter of $7 \pm 1 \mu \mathrm{m}(\text { C. } \text { cinerea })^{47}$ and $10 \pm 3 \mu \mathrm{m}(P$. ultimum $)$ using ImageJ software ${ }^{52}$ following a modified method described by Jenson et al. (Table 1). ${ }^{53}$

\section{Quantification of phage Mass recovery}

The mass recovery $(M)$ was calculated as the ratio of the total number of phages in the effluent and the influent in a given time period $(\Delta \mathrm{t})$ as inferred from the difference of inlet $\left(C_{\mathrm{o}}\right)$ and outlet $\left(C_{\mathrm{t}}\right)$ phage concentration as described by eq. 1

$$
M=\frac{\sum \mathrm{C}_{\mathrm{t}} \Delta \mathrm{t}}{\sum \mathrm{C}_{0} \Delta \mathrm{t}} * 100
$$

\section{Quantification of phage retention}

Prior to addition of phage suspensions the microfluidic devices were carefully flushed with $\approx 100 \mu \mathrm{L}$ of SM buffer $\left(100 \mathrm{mM}\right.$, Ionic strength $\left.\mathrm{I}_{\mathrm{s}} \sim 360 \mathrm{mM}\right)$ to replace the growth media. A syringe pump (KD 
189 Scientific Inc., USA) loaded with Luer-lock syringes (Injekt®Solo, 2 mL, B. Braun, Melsungen,

190 Germany) was used to administer the phage suspension $\left(\approx 3 \times 10^{9} \mathrm{PFU} \mathrm{mL}^{-1}\right)$ into the microfluidic

191 channels at a volumetric flow rate of $5 \mu \mathrm{L} \mathrm{h}^{-1}$ (average velocity: $1.4 \times 10^{-4} \mathrm{~m} \mathrm{~s}^{-1}$; time for fluid to 192 reach outflow: $43 \mathrm{~s}$ (cf. SI)).. After 4 and $22 \mathrm{~h}$ at RT, samples from the inlet and the outlet (i.e. aliquots 193 from the well-mixed effluents after 0-4h $(20 \mu \mathrm{L})$ and $4-22 \mathrm{~h}(90 \mu \mathrm{L}))$ of triplicate microfluidic devices 194 containing mycelia were collected and the phages enumerated. Quadruplicate experiments in mycelia195 free microfluidic devices (control) revealed insignificant $(<2 \%)$ losses of phages in the devices and 196 the tubing material (Fig. $2 \&$ Table 2$)$. The retention of phages to the mycelial surface $\left(R_{\mathrm{P}}\right)$ was 197 calculated using eq. 2, with $C_{\mathrm{t}, \text { effluent }}$ and $C_{\mathrm{t}, \text { influent }}$ being the effluent and the influent phage 198 concentrations respectively, $\mathrm{C}_{\mathrm{t}}$, effluent, control the effluent phage concentrations in mycelia-free controls, $199 V_{\mathrm{t}, \text { effluent }}$ the volume of effluent at sampling $\left(20 \mu \mathrm{L}\right.$ and $90 \mu \mathrm{L}$ after $4 \mathrm{~h}$ and $22 \mathrm{~h}$, resp.) and $A_{\text {mycelia }}$ the 200 estimated surface area of the mycelia in $\mathrm{mm}^{2}$.

$$
R_{\mathrm{P}}=\frac{\left(\left(C_{\mathrm{t}, \text { influent }}-C_{\mathrm{t}, \text { effluent }}\right)-\left(C_{\mathrm{t}, \text { influent }}-C_{\mathrm{t}, \text { effluent,control }}\right)\right) * V_{\mathrm{t}, \mathrm{effluent}}}{A_{\text {mycelia }}}
$$

202 The t-test (two-tailed distribution) was used to test for significance and to determine the level of 203 marginal significance (p-value).

\section{Calculations of phage-hyphal surface interaction energies}

206 The total interaction energy $\left(G_{\text {XDLVO }}\right)$ between phages and hyphal surfaces was predicted by the extended Derjaguin-Landau-Verwey-Overbeek (XDLVO) theory of colloidal interactions. ${ }^{54} G_{\text {XDLVO }}$ 208 is the sum of the electrostatic repulsion $\left(G_{\mathrm{EDL}}\right)$, the Lifshitz-van der Waals $\left(G_{\mathrm{LW}}\right)$ and the acid-base $209\left(G_{\mathrm{AB}}\right)$ interaction energy. While $G_{\mathrm{AB}}$ compares the energy status between attached and nonattached 210 situations, $G_{\mathrm{EDL}}$ and $G_{\mathrm{LW}}$ are functions of the separation distance, $h(\mathrm{~nm})$, between two surfaces ${ }^{55,56}$ 211 (eq. 3):

$$
G_{\mathrm{XDLVO}}(h)=G_{\mathrm{AB}}+G_{\mathrm{EDL}}(h)+G_{\mathrm{LW}}(h)
$$


213 Sphere-plate geometry was applied as phages are far smaller than the hyphal surfaces. ${ }^{57} G_{\mathrm{EDL}}, G_{\mathrm{LW}}$

214 and $G_{\mathrm{AB}}$ were calculated as described previously. ${ }^{22}$ Surface free energy calculations were based on

215 measured contact angles of phages and fungi using water, formamide and methylene iodide as liquids

216 (as described above) and the Young equation. ${ }^{58}$ The Gibbs free energies (Table S1) and Hamaker

217 constants were calculated using the surface free energies of studied phages and hyphal surfaces 218 applying eq. S4 and eq. S11.

\section{RESULTS}

\section{Phage transport in microfluidic devices}

222 Interactions of phages with hyphal surfaces were investigated using a microfluidic platform under 223 continuous flow conditions typical for subsurface water flows $\left(1.2 \mathrm{~m} \mathrm{~d}^{-1}\right)^{59}$ (Fig. 1) by comparing the 224 in- and effluent phage concentrations (Fig. 2; Table 2). Control experiments in the absence of mycelia 225 (Table 2, Fig S2) revealed negligible $(<2 \%)$ differences between in- and effluent phage concentrations 226 (Table 2). Water contact angle measurements revealed that $C$. cinerea $\left(\theta_{\mathrm{w}}=131 \pm 2^{\circ}\right)$ and $P$. ultimum $227\left(\theta_{\mathrm{w}}=62 \pm 6^{\circ}\right)$ were highly and moderately hydrophobic respectively. The T4 and PSA-HS2 phages 228 were of similar size $(\approx 200 \mathrm{~nm})$ and surface charge $(\zeta \approx-10 \mathrm{mV})$ yet differed in surface hydrophobicity 229 (T4: $\theta_{\mathrm{w}}=95^{\circ} ;$ PSA-HS2: $\theta_{\mathrm{w}}=40^{\circ}$; Table 1$)$.

230 In the presence of $P$. ultimum, differences between the PFU counts of PSA-HS2 and T4 phages in the 231 in- and effluents of the microfluidic devices were small (i.e., $<4 \%)$ and statistically not significant (p $232>0.05)$ at both time intervals $(0-4 \mathrm{~h}$ and $4-22 \mathrm{~h})($ Fig. $2 \mathrm{~A} \& \mathrm{C}$ and Table 2$)$. The presence of highly 233 hydrophobic $C$. cinerea hyphae, however, resulted in $\approx 25 \%$ (PSA-HS2) and 90\% (T4) reductions of 234 the outflow concentration of the hydrophilic PSA-HS2 (Fig. 2B) and hydrophobic T4 phages (Fig. 2D) 235 after $4 \mathrm{~h}(\mathrm{p} \leq 0.05)$. This corresponds to a mass recovery of $M=7 \%$ (T4) and $M=77 \%$ (PSA-HS2) 236 during the first $4 \mathrm{~h}$ of phage percolation (Table 2). Most likely due to blocking effects of the hyphal 237 collector (i.e., hyphal surface became progressively occluded), the retention of T4 phages was 
minimized as similar PFU counts for the effluents and controls were observed after $22 \mathrm{~h}$. As the hyphal density and morphology of the two mycelia differed (cf. Fig. 1C \& D), micrographs of the hyphal structures in the observation chambers were taken, and the hyphal surface areas exposed to the percolating phages were estimated (Table 1). After $4 \mathrm{~h}$, the calculated apparent (yet statistically not significant) retention of phages to the mycelial surface $\left(R_{\mathrm{P}}\right)$ of $P$. ultimum was $\approx 2.3 \times 10^{6} \mathrm{PFU} \mathrm{mm}{ }^{-2}$ for T4 and $4.3 \times 10^{6} \mathrm{PFU} \mathrm{mm}{ }^{-2}$ for phage PSA-HS2 (Table 2). The presence of the hydrophobic surface

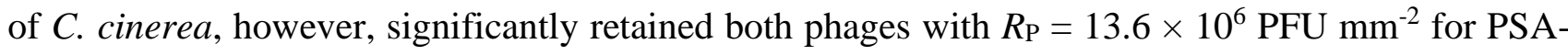
HS2 and $R_{\mathrm{P}}=36.7 \times 10^{6} \mathrm{PFU} \mathrm{mm} \mathrm{m}^{-2}$ for T4 phages $(\mathrm{p} \leq 0.05$; Fig. 3 ). This results in estimated time-

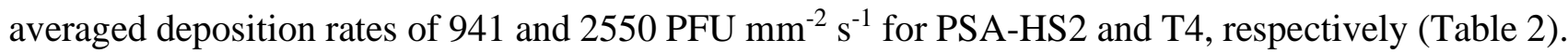
Better phage retention by more hydrophobic mycelia of $C$. cinerea was also evidenced by smaller mass recovery of T4 and PSA-HS2 phages (Table 2).

\section{Effect of mycelial conditioned media on phage infectivity and colloidal stability}

As mycelial products may influence the stability and infectivity of phages, the effect of $P$. ultimum and $C$. cinerea conditioned media on the PFU counts of T4 and PSA-HS2 was quantified after exposing the phages to the conditioned media for 0,4 , and $22 \mathrm{~h}$. After $4 \mathrm{~h}$ no statistically significant reduction on PSA-HS2 and T4 phage concentrations was observed (Table 2, Fig. S1). Similarly, no effects of the conditioned media on PSA-HS2 phage counts were observed after $22 \mathrm{~h}$ of exposure. By contrast, the highly hydrophobic T4 phages exhibited a slight, yet statistically significant $(p \leq 0.05)$ decrease of $\approx 14 \%$ PFU counts in the conditioned medium of $C$. cinerea yet not of $P$. ultimum ( $\approx 6 \%$ decrease).

\section{Approximation of phage-hyphal surface interaction energies}

260 Phage-hyphal surface interaction energy $\left(G_{\text {XDLVO }}\right)$ profiles were calculated using the XDLVO theory 261 (cf. eq. 3 \& eq. S2) based on the sphere-plate model (Fig. 4, Table 1). ${ }^{57}$ This model is well-accepted 262 approach to estimate the interaction energies of a phage approaching a surface, ${ }^{57,60}$ although phages 
263 are away from the uniform surfaces of colloidal particles. The $G_{\text {XDLVO }}$ is characterized by three 264 different interaction energies: the primary minimum $\left(\Phi_{\min 1}\right)$ as the deep energy at short separation 265 distance $h$ from the sorbent surface, the secondary minimum $\left(\Phi_{\min 2}\right)$ as the shallow energy at larger 266 distances allowing for reversible phage adhesion, and the maximum energy barrier (i.e. the energy the 267 phages need to overcome to get irreversibly attached at the $\left.\Phi_{\min 1}\right)\left(\Phi_{\max 1}\right) .{ }^{61,62}$ For the given 268 experimental conditions, the $G_{\mathrm{XDLV}}$ profiles predicted either no ( $\Phi_{\max 1}$ : no to be calculated) or low $269\left(\Phi_{\max 1}=4.7 \times 10^{-3} \mathrm{k}_{\mathrm{B}} \mathrm{T}\right.$ at $h \approx 10 \mathrm{~nm}$; PSA-HS2) maximum energy barriers for the interactions of $P$. 270 ultimum with T4 and PSA-HS2 phages, respectively (Table 2, Fig. 4). This indicates that both phages, 271 if retained by the hyphae of $P$. ultimum, would be attracted directly to the primary minimum $\Phi_{\min 1}$. 272 However, no T4 phage) and a very weak secondary minimum $\left(\Phi_{\min 2}=-2.7 \times 10^{-4} \mathrm{k}_{\mathrm{B}} \mathrm{T}\right.$ at $\left.h \approx 12 \mathrm{~nm}\right)$ 273 for PSA-HS2 phage was calculated and, hence, poor reversible retention of both phages by P. ultimum 274 surfaces predicted by the XDLVO approach. ${ }^{63,64}$ For interactions of the hyphal surface of $C$. cinerea, 275 the XDLVO approach predicted the absence of $\Phi_{\max 1}$ for both phages and more negative primary 276 minima than for P. ultimum (Table 2, Fig. 4). No secondary minima were found, yet attractive $G_{\mathrm{XDLVO}}$ 277 values, however, were calculated up to $h \approx 100 \mathrm{~nm}$ and $\mathrm{h} \approx 40 \mathrm{~nm}$ above the $C$. cinerea hyphal surfaces 278 for T4 and PSA-HS2 phages, respectively.

280 DISCUSSION

\section{Effect of mycelia on phage transport and retention}

282 We studied the interactions between phages and mycelia at the micrometer scale using a bespoke microfluidic platform. The so-called "Soil-on-a-Chip" microfluidic technology for organismal studies 284 is an emerging field, ${ }^{65}$ which allows for the precise control of the physico-chemical microenvironment, 285 high-resolution imaging and the simulation of environmental complexity on the microscale. ${ }^{\mathbf{6 6}} \mathrm{We}$ 286 assessed the interaction of phages with hyphae both in a quantitative manner and at the level of single hyphae. To our knowledge, this is the first study of its kind to analyze the role of hyphae on the 
transport and retention of nano-sized particles (phages). For this purpose, two lytic phages of different morphology and physical-chemical properties were applied, i.e., the T4 coli-phage and the marine phage PSA-HS2. The phages were injected into microfluidic channels containing growing mycelia of 291 known structure and differing hydrophobicity and the time-averaged retention of the phages was

292 calculated. Mycelia of the oomycete $P$. ultimum and of the hydrophobic agaricomycete $C$. cinerea 293 were employed. Phage decay due to experimental conditions in the absence of mycelia was negligible 294 and accounted for in our experiments. . Our data suggest that passage through microfluidic devices in the presence of moderately hydrophobic mycelia (P. ultimum) didn't lead to statistically verifiable 296 phage retention (Table 2). The highly hydrophobic mycelia of $C$. cinerea, however, efficiently retained 297 both phages (as reflected by increased $R_{\mathrm{P}}$ values) and significantly $(\mathrm{p} \leq 0.05)$ reduced mass recovery 298 (T4: > $93 \%$; PSA-HS2: and > $23 \%$ ) relative to mycelia free controls (Table 2). Differences in the 299 phage recovery also demonstrate higher retention of the hydrophobic phage T4 than of the more 300 hydrophilic PSA-HS2 phage. Most likely due to saturation of possible sorption sites, T4 however, 301 showed no significant additional retention by C. cinerea in the observation period up to $22 \mathrm{~h}$ (Fig. 2D) 302 while apparent saturation of the hyphal surface for PSA-HS2 phages was not yet reached (Fig. 2C). 303 Our findings are consistent with previous studies showing that hydrophobic phages (and other viruses) 304 are more efficiently retained than hydrophilic phages ${ }^{\mathbf{6 7 , 6 8 , 2 2}}$ They further reveal that sorption of viruses 305 strongly depends on the surface properties of both the viruses and the sorbent; for instance, positively 306 charged sorbents have been considered as ideal materials for the removal of viruses from aqueous 307 systems. ${ }^{\mathbf{6 9 , 7 0}}$ Our results likewise emphasize for the first time the role of hydrophobic interactions for 308 the interaction between phages and hyphal surfaces. ${ }^{67}$

309 As hyphal metabolites or extracellular products are known to foster coagulation ${ }^{71,39}$ and hence may 310 reduce colloidal stability and possible infectivity of phages, we further studied the impact of mycelial 311 conditioned media on the infectivity of T4 and PSA-HS2 phage suspensions. With the exception of a 312 slight (14\%) reduction of T4 phage counts after $22 \mathrm{~h}$, no influence of mycelial conditioned media on 
313 total phage counts (i.e., phage infectivity) was observed (Fig. S1). Similar to the known effect of solid

314 matrices, ${ }^{72,73}$ it even may be speculated that fungal surfaces may protect viruses from inactivation. ${ }^{72,73}$

315 The reasons for the reduction of T4 phages in the presence of $C$. cinerea conditioned medium after 22

$316 \mathrm{~h}$ remain though unclear, yet are likely to be explained by the effect of extracellular mycelial products

317 in the conditioned media (e.g., glycoprotein mucilages) that may influence colloidal stability rather

318 than the infectivity of T4 phages. An additional effect on the reduced T4 phage stability may be caused

319 by the CCMM medium, as mycelia-free controls also exhibited stability of $93 \pm 4 \%$ (Fig. S2). Our

320 data hence suggest the absence of mycelial effects on the infectivity and colloidal stability of the

321 phages in the microfluidic devices. They underpin the relevance of phage deposition as the main driver

322 for the reduced mass recoveries observed in the presence of the hydrophobic surfaces of $C$. cinerea.

\section{Phage-hyphal surface interaction energies}

325 Phages are charged colloidal particles ${ }^{69}$ and believed to follow the principles of colloid chemistry 326 despite of their morphological and structural variability. ${ }^{54}$ Applying the XDLVO approach, we 327 calculated the surface interaction energies as a function of the surface-to-surface distance, $h$, for a 328 phage approaching a mycelial surface (eq. 3, Fig. 4). The XDLVO interaction energy is characterized 329 by the primary minimum $\left(\Phi_{\min 1}\right)$, the secondary minimum $\left(\Phi_{\min 2}\right)$ and the maximum energy barrier $330\left(\Phi_{\max 1}\right) .{ }^{57}$ The XDLVO calculations predicted poor interactions of T4 and PSA-HS2 phages with 331 hyphal surfaces of $P$. ultimum as evidenced by shallow $\Phi_{\min 2}\left(-3 \times 10^{-4} \mathrm{k}_{\mathrm{B}} \mathrm{T}\right)$ for the PSA-HS2 phage ${ }^{64}$ 332 and poorly negative $G_{X D L V O}$ profiles $\left(>\approx-8 \times 10^{-4} \mathrm{k}_{\mathrm{B}} \mathrm{T}\right)$ at distances $\mathrm{h}>10 \mathrm{~nm}$ above the surfaces for 333 the T4 phage (Fig 4). Only at close distances $(\mathrm{h}<\approx 10 \mathrm{~nm})$ to the hyphal surface, phages with a small 334 kinetic energy ${ }^{57}$ would be able to overcome the very low maximum energy barriers and get 335 (irreversibly) attached in the primary minimum. These predictions are in good agreement with our 336 experimental results showing less phage retention by $P$. ultimum than by $C$. cinerea hyphal surfaces 337 (Figs. $2 \& 3$ ). For the latter, the GXDLvo profiles of T4 and PSA-HS2 interactions exhibited clearly 
negative $G_{X D L V O}$ values up to $h \approx 40 \mathrm{~nm}$ (PSA-HS2: $-1.73 \mathrm{k}_{\mathrm{B}} \mathrm{T}$ at $h=10 \mathrm{~nm}$ to $-0.06 \mathrm{k}_{\mathrm{B}} \mathrm{T}$ at $\left.h=40 \mathrm{~nm}\right)$ and up to $h \approx 145 \mathrm{~nm}$ (T4: $-3.62 \mathrm{kB}$ at $h=10 \mathrm{~nm}$ to $-0.06 \mathrm{k}_{\mathrm{B}} \mathrm{T}$ at $h=145 \mathrm{~nm}$ ) respectively and thus remain attractive up to longer separation distances than for hyphal surfaces of $P$. ultimum (Fig. 4). the XDLVO predictions reflect the experimentally observed differences of retention of T4 and PSA-HS2 phages by mycelia of $C$. cinerea and $P$. ultimum respectively (Fig. $2 \& 3$ ) and supports the applicability of XDLVO approach to study the interactions of phages with surfaces. ${ }^{60}$

\section{Implications for phage transport}

346 The mobilization of colloids or bio-colloids such as bacteria and viruses in soil often is triggered by, snowmelts, or thunderstorms or high-intensity rain events that lead to high loads of the seepage water. ${ }^{74}$

348 Rapid waterborne transport thereby may occur along macro-pores, cracks, or faults of the partly 349 saturated soil, and hence in cavities where mycelia and their thread-like, adaptive and fractal 350 networks ${ }^{75,76,35,36}$ may be typically found. ${ }^{77}$ Depending on the soil type, filamentous fungi may exhibit 351 dry weight biomasses of up to $45 \mathrm{t}^{\mathrm{per}} \mathrm{ha}^{33}$ and corresponding hyphal lengths of up to $10^{2} \mathrm{~m} \mathrm{~g}^{-1}$ (arable soil) $-10^{4} \mathrm{~m} \mathrm{~g}^{-1}$ (forest soil). Given a retention of phages to the mycelial surface of $R_{\mathrm{P}}=10^{7} \mathrm{PFU} \mathrm{mm}$ 2 and a presumed hyphal diameter of $10^{-5} \mathrm{~m}$, such fungal biomass would translate to a calculated mycelial surface of $\approx 0.0031-0.3140 \mathrm{~m}^{2}$ or a hypothetical phage retention potential of $3 \times 10^{10}$ to $3 \times$ $10^{12}$ phages per gram of soil. This would correspond to 30 to 3000 times the reported average number of virus like particles per gram of soil, ${ }^{78,79}$ and, hence, be an important location for phage retention. Some hyphae are also known to become hydrophobic, ${ }^{50}$ when exposed to air in unsaturated soil conditions or during periods of soil drying. Hydrophobic mycelia may retain phages particularly well when exposed to conditions of soil water flow during major rain events. A recent 1-year time-series analysis of virus-like particle abundances in soils along a transect with different land-use practices, for instance, proposed rainfall-induced mobilization of viruses and correlations between rainfall and virus abundances in non-forest sites. ${ }^{79}$ Furthermore, the physico-chemical effects of phage and hyphal 
surface properties on phage retention to mycelia can influence the structure of soil; for instance, some

364 hyphae exert polysaccharides and glycoprotein mucilages ${ }^{39}$ that enable the aggregation of soil mineral 365 particles and organic matter. ${ }^{71}$ These aggregates play a crucial role in the retention of viruses due to 366 exclusion effects at the pore-scale. ${ }^{80}$ At the micrometer scale, fungi take advantage of the three367 dimensional space in the soil. ${ }^{48}$ Their small hyphal diameter, which is approximately $1 / 60^{\text {th }}$ the 368 thickness of roots, allows fungi to access tight spaces. ${ }^{30}$ This promotes the possible role that hyphae 369 may play in the transport of colloidal particles, as bonding forces tend to be stronger at smaller size 370 scales. ${ }^{39}$ Consequently, understanding phage-mycelial interactions may help in planning different 371 environmental and health related applications. For instance, tracer phages, which exhibit less retention 372 in the presence of fungal mycelia, will be better tracer phages for tracer studies in terrestrial 373 ecosystems. On the other hand, fungal mycelia with high phage retention potential can be used in the 374 design of filter systems to reduce or hinder the transport of undesirable entities, e.g., pathogenic 375 viruses, bacteria or anthropogenic nanoparticles. Accordingly, investigations concerning the influence 376 of mycelia on the retention of phages could be extended to nanoparticles, which will be of interest for 377 different applications. Further, the retention of phages by mycelia may increase the phage accessibility 378 to bacteria, influence the multifarious bacterial-fungal interactions,${ }^{81,34}$ and/or promote phage-induced 379 gene mobility in microbiomes of the mycosphere. Future work will need to include studies under more 380 complex environmental conditions.

\section{ACKNOWLEDGMENTS}

383 This study is part of the Collaborative Research Centre AquaDiva (CRC 1076 AquaDiva) at the 384 Friedrich Schiller University Jena and the Helmholtz Centre for Environmental Research - UFZ and 385 was funded by the Deutsche Forschungsgemeinschaft (DFG). C.E.S. also acknowledges financial support by the Swiss National Science Foundation (Ambizione Grant No. PZ00P2_168005). The 
388 skilled technical help as well as Bijing Xiong (UFZ) for the photograph of the microfluidic device used 389 in Fig. 1C and the TOC. The authors further thank Tom Berthold, Anja Worrich and René Kallies for 390 helpful discussions and Prof. M. Künzler (ETH Zürich) for kindly providing C. cinerea strain 391 AmutBmut pMA412.

393 SUPPLEMENTARY MATERIAL

394 Supporting Information is available and contains three figures and two tables. 395

396 CONFLICT OF INTEREST

397 The authors declare that the research was conducted in the absence of any commercial or financial 398 relationships that could be construed as a potential conflict of interest. 
Figure 1. (A) Photograph of the microfluidic platform used to monitor phage-mycelial interactions. A 403 mycelial inoculum was placed next to the lateral opening of the microfluidic device (made from poly(dimethylsiloxane) (PDMS) silicone elastomer), allowing hyphae to penetrate and grow into the observation channel via a constriction channel, as illustrated in the two-dimensional overview of the microchannel geometry (B). Hyphal growth was observed in the observation channel, as indicated by the red dotted frame in (B), using bright field or fluorescence microscopy

(C) A bright-field micrograph of $P$. ultimum hyphae (24 h post inoculation). (D) A fluorescence micrograph of $C$. cinerea hyphae (48 h post inoculation). The direction of hyphal growth was toward the outlet.

411 Figure 2. PSA-HS2 and T4 phage concentrations in the influent (light grey bars) and the effluent of 412 the microfluidic devices in the absence (black) and presence (grey) of hyphae after 4 and $22 \mathrm{~h}$ of 413 continuous flow $\left(5 \mu \mathrm{L} \mathrm{h}^{-1}\right)$. Phages were enumerated by plaque forming units (PFU) depicted by total 414 (primary y-axis on the left hand side of each panel). Data represent averages and standard deviations 415 of triplicate experiments (except for duplicates for PSA-HS2 with C. cinerea). The asterisks on top of 416 the columns refer to statistically significant differences (determined using two-tailed t-test) between 417 the effluent concentration (in the presence of hyphae) and the corresponding controls (i.e. influent 418 concentration and effluent concentration in the absence of hyphae): $\mathrm{p} \leq 0.05(*), \mathrm{p} \leq 0.01(* *)$ and $\mathrm{p} \leq$ $4190.001(* * *)$.

421 Figure 3. Total number of T4 or PSA-HS2 phages retained per $\mathrm{mm}^{2}$ of the mycelial surface after $4 \mathrm{~h}$ 422 of phage percolation through the microfluidic devices containing either hyphae of $P$. ultimum or C. 423 cinerea. Data represent averages and standard deviations of triplicate experiments (except for 
424 duplicates for PSA-HS2 \& C. cinerea). Asterisks indicate significant differences, if present, between 425 different phage and mycelia pairs: $\mathrm{p} \leq 0.01(* *)$ and $\mathrm{p} \leq 0.001(* * *)$.

427 Figure 4. XDLVO interaction energy profiles between phages and mycelia. The interaction energy 428 profiles show the overall interaction energy (GXDLVO; black solid line), the acid-base interaction 429 energy (GAB; orange long-dashed line), the electrostatic repulsion (GEDL; blue short-dashed line), 430 and the Lifshitz-van der Waals energy ( $G \mathrm{LW}$; red dotted-dashed line) as a function of distance particle $431 h(\mathrm{~nm})$ between the phage and the mycelia surface. 
432 Table 1. Overview of the names, classifications, size and physico-chemical surface properties of the 433 phages and hyphal organisms used in this study.

434

435

\begin{tabular}{|c|c|c|c|c|c|}
\hline $\begin{array}{l}\text { Name } \\
\text { (Name of family or class) }\end{array}$ & Phage host name & $\begin{array}{c}\text { Zeta potential } \\
\zeta\end{array}$ & $\begin{array}{c}\text { Water contact angle } \\
\Theta_{w}\end{array}$ & $\begin{array}{c}\text { Size } \\
\text { (head/tail) }\end{array}$ & Surface area \\
\hline & & $(\mathrm{mV})$ & (degree) & $(\mu \mathrm{m})$ & $\left(\mathrm{mm}^{2}\right)$ \\
\hline $\begin{array}{l}\text { PSA-HS2 } \\
\text { (Siphoviridae) }\end{array}$ & Pseudoalteromonas $\mathrm{H} 13-15$ & $-10 \pm 1$ & $40 \pm 5^{\text {a) }}$ & $\begin{array}{c}0.21 \text { a) } \\
(0.06 / 0.15) \text { a) }\end{array}$ & -- \\
\hline $\begin{array}{l}\text { T4 } \\
\text { (Myoviridae) }\end{array}$ & E. coli (Migula 1895) & $-10 \pm 2$ & $95 \pm 5^{\text {a) }}$ & $\begin{array}{c}0.203^{a)} \\
(0.09 / 0.113)^{a)}\end{array}$ & -- \\
\hline $\begin{array}{l}\text { Pythium ultimum } \\
\text { (Oomycete) }\end{array}$ & -- & $-11 \pm 3$ & $62 \pm 6$ & $10 \pm 3^{b)}$ & $1.2 \pm 0.1^{c)}$ \\
\hline $\begin{array}{l}\text { Coprionopsis cinerea } \\
\text { strain AmutBmut pMA412 } \\
\text { (Agaricomycete) }\end{array}$ & -- & $-13 \pm 4$ & $131 \pm 2$ & $7 \pm 1^{b)}$ & $0.9 \pm 0.4^{c)}$ \\
\hline
\end{tabular}

437 a) Data taken from Ghanem et al. ${ }^{22}$ b) Average and standard deviations ( $\mathrm{n} \geq 20$ ) of hyphal diameters, ${ }^{c}$ Average and standard deviations of 438 the surface area of mycelia $(n>5)$ after $24 \mathrm{~h}(P$. ultimum) and $48 \mathrm{~h}(C$. cinerea) of inoculation. 
440 Table 2. Calculated retention (RP) of phages to mycelial surfaces $(0-4 \mathrm{~h})$ and mass recoveries $(M)$ of transport experiments in microfluidic 441 devices, as well as the stability and viability of phage suspensions in the presence of $P$. ultimum and $C$. cinerea conditioned media. The values of 442 the maximum energy barrier $\left(\Phi_{\max 1}\right)$, the primary minimum $\left(\Phi_{\min 1}\right)$, and the secondary minimum $\left(\Phi_{\min 2}\right)$ of phage-mycelia interaction energies 443 were derived based on the XDLVO approach using a sphere-plate model.

444

\begin{tabular}{|c|c|c|c|c|c|c|c|c|}
\hline $\begin{array}{l}\text { Phage } \\
\text { name }\end{array}$ & $\begin{array}{l}\text { Name of hyphal } \\
\text { organisms }\end{array}$ & $\begin{array}{c}\text { Retention of phages } \\
\text { to mycelial surface } \\
\left(R_{P}\right) \\
\text { after } 0-4 h a, b)\end{array}$ & $\begin{array}{c}\text { Phage mass recovery } \\
\text { with mycelia } \\
\text { after } 0-4 \mathrm{~h} \\
(4-22 \mathrm{~h})^{\mathrm{b})} \\
M\end{array}$ & $\begin{array}{c}\text { Phage mass recovery } \\
\text { without mycelia } \\
\text { after } 0-4 \mathrm{~h} \\
(4-22 \mathrm{~h})^{\mathrm{b})} \\
M\end{array}$ & $\begin{array}{l}\text { Phage stability } \\
\text { after } 4 \mathrm{~h} \\
\text { (after } 22 \mathrm{~h} \text { ) }^{\mathrm{c})}\end{array}$ & $\begin{array}{c}\begin{array}{c}\text { Calculated } \\
\text { maximum energy } \\
\text { barrier d) }\end{array} \\
\Phi \max 1\end{array}$ & $\begin{array}{c}\begin{array}{c}\text { Calculated } \\
\text { energy at primary } \\
\text { minimum (d) }\end{array} \\
\Phi \min 1\end{array}$ & $\begin{array}{c}\text { Calculated energy } \\
\text { at secondary } \\
\text { minimum d) } \\
\Phi \text { min2 }\end{array}$ \\
\hline & & $\left(\mathrm{PFU} \mathrm{mm}^{-2} \times 10^{6}\right)$ & $(\%)$ & $(\%)$ & $(\%)$ & $\left(\mathrm{k}_{\mathrm{B}} \mathrm{T} \times 10^{-3}\right)$ & $\left(\mathrm{k}_{B} \mathrm{~T} \times 10^{4}\right)$ & $\left(\mathrm{k}_{\mathrm{B}} \mathrm{T} \times 10^{-3}\right)$ \\
\hline \multirow[t]{2}{*}{ PSA-HS2 } & Pythium ultimum & $4.26 \pm 0.6$ & $\begin{array}{c}92 \pm 3 \\
(108 \pm 12)\end{array}$ & $\begin{array}{c}98 \pm 5 \\
(94 \pm 0)\end{array}$ & $\begin{array}{c}97 \pm 23 \\
(98 \pm 16)\end{array}$ & 4.7 & -1.1 & -0.3 \\
\hline & Coprinopsis cinerea & $13.6 \pm 1.3$ & $\begin{array}{c}77 \pm 2 \\
(75 \pm 6)\end{array}$ & $\begin{array}{l}99 \pm 0.2 \\
(97 \pm 0)\end{array}$ & $\begin{array}{l}102 \pm 11 \\
(99 \pm 16)\end{array}$ & $n a^{\text {e) }}$ & -1.9 & $\mathrm{na}^{\mathrm{d})}$ \\
\hline \multirow[t]{2}{*}{ T4 } & Pythium ultimum & $2.3 \pm 0.8$ & $\begin{array}{c}98 \pm 4 \\
(107 \pm 15)\end{array}$ & $\begin{array}{c}99 \pm 1 \\
(109 \pm 7)\end{array}$ & $\begin{array}{l}108 \pm 6 \\
(94 \pm 3)\end{array}$ & $n a^{e)}$ & -14 & $n a^{\mathrm{e})}$ \\
\hline & Coprinopsis cinerea & $36.7 \pm 0.61$ & $\begin{array}{c}7 \pm 1 \\
(86 \pm 11)\end{array}$ & $\begin{array}{c}98 \pm 5 \\
(92 \pm 0.5)\end{array}$ & $\begin{array}{l}106 \pm 5 \\
(86 \pm 6)\end{array}$ & $n a^{\text {e) }}$ & -29 & $\mathrm{na}^{\mathrm{e})}$ \\
\hline
\end{tabular}

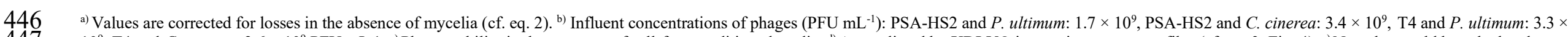

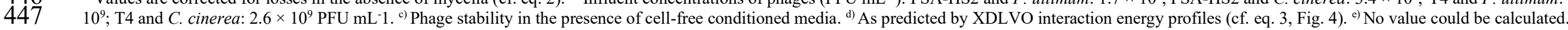


451 (1) Paul, J. H.; Rose, J. B.; Brown, J.; Shinn, E. A.; Miller, S.; Farrah, S. R. Viral Tracer Studies 452 Indicate Contamination of Marine Waters by Sewage Disposal Practices in Key Largo, Florida. Appl. 453 Environ. Microbiol. 1995, 61 (6), 2230-2234.

454 (2) Williamson, K. E.; Harris, J. V.; Green, J. C.; Rahman, F.; Chambers, R. M. Stormwater Runoff 455 Drives Viral Community Composition Changes in Inland Freshwaters. Front. Microbiol. 2014, 5, 105. 456 https://doi.org/10.3389/fmicb.2014.00105.

457 (3) Collins, K. E.; Cronin, A. A.; Rueedi, J.; Pedley, S.; Joyce, E.; Humble, P. J.; Tellam, J. H. 458 Fate and Transport of Bacteriophage in UK Aquifers as Surrogates for Pathogenic Viruses. Eng. Geol. 459 2006, 85 (1-2), 33-38. https://doi.org/10.1016/j.enggeo.2005.09.025.

460 (4) McKay, L. D.; Cherry, J. A.; Bales, R. C.; Yahya, M. T.; Gerba, C. P. A Field Example of 461 Bacteriophage as Tracers of Fracture Flow. Environ. Sci. Technol. 1993, 27 (6), 1075-1079.

462 (5) Flynn, R. M.; Mallèn, G.; Engel, M.; Ahmed, A.; Rossi, P. Characterizing Aquifer 463 Heterogeneity Using Bacterial and Bacteriophage Tracers. J. Environ. Qual. 2015, 44 (5), 1448. 464 https://doi.org/10.2134/jeq2015.02.0117.

465 (6) Harvey, R. W.; Harms, H.; Landkamer, L. Transport of Microorganisms in the Terrestrial 466 Subsurface: In Situ and Laboratory Methods. Man. Environ. Microbiol. 2002, 2, 753-776.

467 (7) Rossi, P. Advances in biological tracer techniques for hydrology and hydrogeology using 468 bacteriophages, Université de Neuchâtel, 1994.

469 (8) Flynn, R.; Hunkeler, D.; Guerin, C.; Burn, C.; Rossi, P.; Aragno, M. Geochemical Influences 470 on H40/1 Bacteriophage Inactivation in Glaciofluvial Sands. Environ. Geol. 2004, 45 (4), 504-517.

471 (9) Goldscheider, N.; Haller, L.; Poté, J.; Wildi, W.; Zopfi, J. Characterizing Water Circulation 472 and Contaminant Transport in Lake Geneva Using Bacteriophage Tracer Experiments and 473 Limnological Methods. Environ. Sci. Technol. 2007, 41 (15), 5252-5258. 474 https://doi.org/10.1021/es070369p.

475 (10) Flynn, R. M.; Sinreich, M. Characterisation of Virus Transport and Attenuation in Epikarst 476 Using Short Pulse and Prolonged Injection Multi-Tracer Testing. Water Res. 2010, 44 (4), 1138-1149. 477 https://doi.org/10.1016/j.watres.2009.11.032.

478 (11) Zhao, B.; Zhang, H.; Zhang, J.; Jin, Y. Virus Adsorption and Inactivation in Soil as Influenced 479 by Autochthonous Microorganisms and Water Content. Soil Biol. Biochem. 2008, 40 (3), 649-659. 480 https://doi.org/10.1016/j.soilbio.2007.09.020.

481 (12) Moore, R. S.; Taylor, D. H.; Sturman, L. S.; Reddy, M. M.; Fuhs, G. W. Poliovirus Adsorption 482 by 34 Minerals and Soils. Appl. Environ. Microbiol. 1981, 42 (6), 963-975.

483 (13) Van Cuyk, S.; Siegrist, R. L. Virus Removal within a Soil Infiltration Zone as Affected by 484 Effluent Composition, Application Rate, and Soil Type. Water Res. 2007, 41 (3), 699-709. 485 https://doi.org/10.1016/j.watres.2006.07.021. 
(14) Kinoshita, T.; Bales, R. C.; Maguire, K. M.; Gerba, C. P. Effect of PH on Bacteriophage Transport through Sandy Soils. J. Contam. Hydrol. 1993, 14 (1), 55-70. https://doi.org/10.1016/01697722(93)90041-P.

(15) Carlson, G. F.; Woodard, F. E.; Wentworth, D. F.; Sproul, O. J. Virus Inactivation on Clay

(16) Taylor, D. H.; Moore, R. S.; Sturman, L. S. Influence of PH and Electrolyte Composition on Adsorption of Poliovirus by Soils and Minerals. Appl. Environ. Microbiol. 1981, 42 (6), 976-984.

(17) Lance, J. C.; Gerba, C. P. Effect of Ionic Composition of Suspending Solution on Virus Adsorption by a Soil Column. Appl. Environ. Microbiol. 1984, 47 (3), 484-488.

(18) Anders, R.; Chrysikopoulos, C. V. Transport of Viruses Through Saturated and Unsaturated Columns Packed with Sand. Transp. Porous Media 2009, 76 (1), 121-138. https://doi.org/10.1007/s11242-008-9239-3.

(19) Trouwborst, T.; Kuyper, S.; De Jong, J. C.; Plantinga, A. D. Inactivation of Some Bacterial and Animal Viruses by Exposure to Liquid-Air Interfaces. J. Gen. Virol. 1974, 24 (1), 155-165.

(20) Dika, C.; Duval, J. F. L.; Francius, G.; Perrin, A.; Gantzer, C. Isoelectric Point Is an Inadequate Descriptor of MS2, Phi X 174 and PRD1 Phages Adhesion on Abiotic Surfaces. J. Colloid Interface Sci. 2015, 446, 327-334. https://doi.org/10.1016/j.jcis.2014.08.055.

(21) Dowd, S. E.; Pillai, S. D.; Wang, S.; Corapcioglu, M. Y. Delineating the Specific Influence of Virus Isoelectric Point and Size on Virus Adsorption and Transport through Sandy Soils. Appl. Environ. Microbiol. 1998, 64 (2), 405-410.

(22) Ghanem, N.; Kiesel, B.; Kallies, R.; Harms, H.; Chatzinotas, A.; Wick, L. Y. Marine Phages As Tracers: Effects of Size, Morphology, and Physico-Chemical Surface Properties on Transport in a Porous Medium. Environ. Sci. Technol. 2016, $50 \quad$ (23), 12816-12824. https://doi.org/10.1021/acs.est.6b04236.

(23) Küsel, K.; Totsche, K. U.; Trumbore, S. E.; Lehmann, R.; Steinhäuser, C.; Herrmann, M. How Deep Can Surface Signals Be Traced in the Critical Zone? Merging Biodiversity with Biogeochemistry Research in a Central German Muschelkalk Landscape. Front. Earth Sci. 2016, 4, 32. https://doi.org/10.3389/feart.2016.00032.

(24) John, D. E.; Rose, J. B. Review of Factors Affecting Microbial Survival in Groundwater. Environ. Sci. Technol. 2005, 39 (19), 7345-7356. https://doi.org/10.1021/es047995w.

(25) Hurst, C. J. Influence of Aerobic Microorganisms upon Virus Survival in Soil. Can. J. Microbiol. 1988, 34 (5), 696-699.

(26) Sobsey, M. D.; Dean, C. H.; Knuckles, M. E.; Wagner, R. A. Interactions and Survival of Enteric Viruses in Soil Materials. Appl. Environ. Microbiol. 1980, 40 (1), 92-101.

(27) Campbell, R. N. Fungal Transmission of Plant Viruses. Annu. Rev. Phytopathol. 1996, 34 (1), 87-108.

(28) Alfaro-Fernández, A.; Del Carmen Córdoba-Sellés, M.; Herrera-Vásquez, J. Á.; Cebrián, M. del C.; Jordá, C. Transmission of Pepino Mosaic Virus by the Fungal Vector Olpidium Virulentus. J. Phytopathol. 2010, 158 (4), 217-226. https://doi.org/10.1111/j.1439-0434.2009.01605.x. 
(29) Varanda, C. M. R.; Silva, M. S. M. R.; Félix, M. do R. F.; Clara, M. I. E. Evidence of Olive Mild Mosaic Virus Transmission by Olpidium Brassicae. Eur. J. Plant Pathol. 2011, 130 (2), 165 172. https://doi.org/10.1007/s10658-011-9742-1.

(30) Pennisi, E. The Secret Life of Fungi. Science 2004, 304 (5677), 1620.

(31) Kendrick, B. The Fifth Kingdom; Focus Pub., 2000.

(32) Kohlmeier, S.; Smits, T. H. M.; Ford, R. M.; Keel, C.; Harms, H.; Wick, L. Y. Taking the Fungal Highway: Mobilization of Pollutant-Degrading Bacteria by Fungi. Environ. Sci. Technol. 2005, 39 (12), 4640-4646. https://doi.org/10.1021/es047979z.

(33) Harms, H.; Schlosser, D.; Wick, L. Y. Untapped Potential: Exploiting Fungi in Bioremediation of Hazardous Chemicals. Nat. Rev. Microbiol. 2011, 9 (3), 177-192. https://doi.org/10.1038/nrmicro2519.

(34) Deveau, A.; Bonito, G.; Uehling, J.; Paoletti, M.; Becker, M.; Bindschedler, S.; Hacquard, S.; Hervé, V.; Labbé, J.; Lastovetsky, O. A.; Mieszkin, S.; Millet, L.J.; Vajna, B.; Junier, P.; Bonfante, P.; Krom, B.P.; Olsson, S.; van Elsas, J.D.; Wick, L.Y.. Bacterial-Fungal Interactions: Ecology, Mechanisms and Challenges. FEMS Microbiol. Rev. 2018, 42 (3), 335-352. https://doi.org/10.1093/femsre/fuy008.

(35) Berthold, T.; Centler, F.; Hübschmann, T.; Remer, R.; Thullner, M.; Harms, H.; Wick, L. Y. Mycelia as a Focal Point for Horizontal Gene Transfer among Soil Bacteria. Sci. Rep. 2016, 6. https://doi.org/10.1038/srep36390.

(36) Zhang, M.; Silva, P. e; C, M. de; De Mares Maryam, C.; Elsas, V.; Dirk, J. The Mycosphere Constitutes an Arena for Horizontal Gene Transfer with Strong Evolutionary Implications for Bacterial-Fungal Interactions. FEMS Microbiol. Ecol. 2014, 89 (3), 516-526. https://doi.org/10.1111/1574-6941.12350.

(37) Wösten, H. A. B.; van Wetter, M.-A.; Lugones, L. G.; van der Mei, H. C.; Busscher, H. J.; Wessels, J. G. H. How a Fungus Escapes the Water to Grow into the Air. Curr. Biol. 1999, 9 (2), 8588. https://doi.org/10.1016/S0960-9822(99)80019-0.

(38) Smits, M. M.; Herrmann, A. M.; Duane, M.; Duckworth, O. W.; Bonneville, S.; Benning, L. G.; Lundström, U. The Fungal-mineral Interface: Challenges and Considerations of Micro-Analytical Developments. Fungal Biol. Rev. 2009, 23 (4), 122-131. https://doi.org/10.1016/j.fbr.2009.11.001.

(39) Ritz, K.; Young, I. M. Interactions between Soil Structure and Fungi. Mycologist 2004, 18 (2), $52-59$.

(40) Deng, L.; Gregory, A.; Yilmaz, S.; Poulos, B. T.; Hugenholtz, P.; Sullivan, M. B. Contrasting Life Strategies of Viruses That Infect Photo- and Heterotrophic Bacteria, as Revealed by Viral Tagging. mBio 2012, 3 (6), e00373-12-e00373-12. https://doi.org/10.1128/mBio.00373-12.

(41) Clokie, M. R.; Millard, A. D.; Letarov, A. V.; Heaphy, S. Phages in Nature. Bacteriophage 2011, 1 (1), 31-45.

(42) Hijnen, W. A. M.; Brouwer-Hanzens, A. J.; Charles, K. J.; Medema, G. J. Transport of MS2 Phage, Escherichia Coli, Clostridium Perfringens, Cryptosporidium Parvum, and Giardia Intestinalis in a Gravel and a Sandy Soil. Environ. Sci. Technol. 2005, 39 (20), 7860-7868. https://doi.org/10.1021/es050427b. 
565 (43) Mohn, G.; Ellenberger, J.; McGregor, D. Development of Mutagenicity Test Using Escherichia 566 Coli K-12 as Indicator Organism. Mutat. Res. 1974, 25 (2), 187-196.

567 (44) Duhaime, M. B.; Solonenko, N.; Roux, S.; Verberkmoes, N. C.; Wichels, A.; Sullivan, M. B. 568 Comparative Omics and Trait Analyses of Marine Pseudoalteromonas Phages Advance the Phage 569 OTU Concept. Front. Microbiol. 2017, 8. https://doi.org/10.3389/fmicb.2017.01241.

570 (45) Oppenheimer, C.; Zobell, C. The Growth and Viability of 63 Species of Marine Bacteria as 571 Influenced. J. Mar. Res. 1952, 11 (1), 10-18.

572 (46) Sezonov, G.; Joseleau-Petit, D.; D’Ari, R. Escherichia Coli Physiology in Luria-Bertani Broth. 573 J. Bacteriol. 2007, 189 (23), 8746-8749. https://doi.org/10.1128/JB.01368-07.

574 (47) Stanley, C. E.; Stöckli, M.; Swaay, D. van; Sabotič, J.; Kallio, P. T.; Künzler, M.; deMello, A. 575 J.; Aebi, M. Probing Bacterial-fungal Interactions at the Single Cell Level. Integr. Biol. 2014, 6 (10), 576 935-945. https://doi.org/10.1039/C4IB00154K.

577 (48) Furuno, S.; Päzolt, K.; Rabe, C.; Neu, T. R.; Harms, H.; Wick, L. Y. Fungal Mycelia Allow 578 Chemotactic Dispersal of Polycyclic Aromatic Hydrocarbon-Degrading Bacteria in Water579 Unsaturated Systems. Environ. Microbiol. 2010, 12 (6), 1391-1398. https://doi.org/10.1111/j.1462$580 \quad 2920.2009 .02022 . x$.

581 (49) Thompson, S. S.; Flury, M.; Yates, M. V.; Jury, W. A. Role of the Air-Water-Solid Interface 582 in Bacteriophage Sorption Experiments. Appl. Environ. Microbiol. 1998, 64 (1), 304-309.

583 (50) Smits, T. H. M.; Wick, L. Y.; Harms, H.; Keel, C. Characterization of the Surface 584 Hydrophobicity of Filamentous Fungi. Environ. Microbiol. 2003, 5 (2), 85-91.

585 (51) Stanley, C.; Shrivastava, J.; Brugman, R.; Heinzelmann, E.; Frajs, V.; Bühler, A.; van Swaay, 586 D.; Grossmann, G. Fabrication and Use of the Dual-Flow-RootChip for the Imaging of Arabidopsis 587 Roots in Asymmetric Microenvironments. BIO-Protoc. 2018, $8 \quad$ (18). 588 https://doi.org/10.21769/BioProtoc.3010.

589 (52) Schneider, C. A.; Rasband, W. S.; Eliceiri, K. W. NIH Image to ImageJ: 25 Years of Image 590 Analysis. Nat. Methods 2012, 9 (7), 671.

591 (53) Jensen, E. C. Quantitative Analysis of Histological Staining and Fluorescence Using ImageJ. 592 Anat. Rec. 2013, 296 (3), 378-381. https://doi.org/10.1002/ar.22641.

593 (54) Syngouna, V. I.; Chrysikopoulos, C. V. Transport of Biocolloids in Water Saturated Columns 594 Packed with Sand: Effect of Grain Size and Pore Water Velocity. J. Contam. Hydrol. 2011, 126 (3-4), 595 301-314. https://doi.org/10.1016/j.jconhyd.2011.09.007.

(55) Boks, N. P.; Norde, W.; van der Mei, H. C.; Busscher, H. J. Forces Involved in Bacterial Adhesion to Hydrophilic and Hydrophobic Surfaces. Microbiology 2008, 154 (10), 3122-3133. https://doi.org/10.1099/mic.0.2008/018622-0.

(56) Bergendahl, J.; Grasso, D. Prediction of Colloid Detachment in a Model Porous Media: 600 Thermodynamics. AIChE J. 1999, 45 (3), 475-484. https://doi.org/10.1002/aic.690450305.

601 (57) Chrysikopoulos, C. V.; Syngouna, V. I. Attachment of Bacteriophages MS2 and X174 onto 602 Kaolinite and Montmorillonite: Extended-DLVO Interactions. Colloids Surf. B Biointerfaces 2012, 92, 603 74-83. https://doi.org/10.1016/j.colsurfb.2011.11.028. 
604 (58) van Oss, C. J.; Docoslis, A.; Wu, W.; Giese, R. F. Influence of Macroscopic and Microscopic 605 Interactions on Kinetic Rate Constants: I. Role of the Extended DLVO Theory in Determining the 606 Kinetic Adsorption Constant of Proteins in Aqueous Media, Using von Smoluchowski's Approach. 607 Colloids Surf. B Biointerfaces 1999, 14 (1-4), 99-104. https://doi.org/10.1016/S0927-7765(99)000286084.

609 (59) Mulligan, A. E.; Charette, M. A. Groundwater Flow to the Coastal Ocean. In Encyclopedia of 610 Ocean Sciences (Second Edition); Steele, J. H., Ed.; Academic Press: Oxford, 2009; pp 88-97. 611 https://doi.org/10.1016/B978-012374473-9.00645-7.

612 (60) Hermansson, M. The DLVO Theory in Microbial Adhesion. Colloids Surf. B Biointerfaces 613 1999, $14(1), 105-119$.

614 (61) van Loosdrecht, M. C.; Lyklema, J.; Norde, W.; Zehnder, A. J. Bacterial Adhesion: A 615 Physicochemical Approach. Microb. Ecol. 1989, 17 (1), 1-15.

616 (62) Jucker, B. A. Polymer Interactions and Bacterial Adhesion. PhD Thesis, ETH Zurich, 1998.

617 (63) Hahn, M. W.; O’Melia, C. R. Deposition and Reentrainment of Brownian Particles in Porous 618 Media under Unfavorable Chemical Conditions: Some Concepts and Applications. Environ. Sci. 619 Technol. 2004, 38 (1), 210-220. https://doi.org/10.1021/es030416n.

620 (64) Shen, C.; Li, B.; Huang, Y.; Jin, Y. Kinetics of Coupled Primary- and Secondary-Minimum 621 Deposition of Colloids under Unfavorable Chemical Conditions. Environ. Sci. Technol. 2007, 41 (20), 622 6976-6982. https://doi.org/10.1021/es070210c.

623 (65) Stanley, C. E.; Grossmann, G.; Solvas, X. C. i; deMello, A. J. Soil-on-a-Chip: Microfluidic 624 Platforms for Environmental Organismal Studies. Lab. Chip 2016, 16 (2), 228-241. 625 https://doi.org/10.1039/C5LC01285F.

(66) Stanley, C. E.; Heijden, M. G. A. van der. Microbiome-on-a-Chip: New Frontiers in PlantMicrobiota Research. Trends Microbiol. 2017, $25 \quad$ (8), 610-613. https://doi.org/10.1016/j.tim.2017.05.001.

(67) Attinti, R.; Wei, J.; Kniel, K.; Sims, J. T.; Jin, Y. Virus' (MS2, ФX174, and Aichi) Attachment on Sand Measured by Atomic Force Microscopy and Their Transport through Sand Columns. Environ. Sci. Technol. 2010, 44 (7), 2426-2432. https://doi.org/10.1021/es903221p.

(68) Dika, C.; Ly-Chatain, M. H.; Francius, G.; Duval, J. F. L.; Gantzer, C. Non-DLVO Adhesion of F-Specific RNA Bacteriophages to Abiotic Surfaces: Importance of Surface Roughness, Hydrophobic and Electrostatic Interactions. Colloids Surf. Physicochem. Eng. Asp. 2013, 435, 178187. https://doi.org/10.1016/j.colsurfa.2013.02.045.

636 (69) You, Y.; Vance, G. F.; Sparks, D. L.; Zhuang, J.; Jin, Y. Sorption of MS2 Bacteriophage to 637 Layered Double Hydroxides. J. Environ. Qual. 2003, 32 (6), 2046-2053.

638 (70) Schijven, J. F.; Hassanizadeh, S. M. Removal of Viruses by Soil Passage: Overview of 639 Modeling, Processes, and Parameters. Crit. Rev. Environ. Sci. Technol. 2000, 30 (1), 49-127. 640 https://doi.org/10.1080/10643380091184174.

641 (71) Bardgett, R. The Biology of Soil: A Community and Ecosystem Approach; Biology of Habitats 642 Series; Oxford University Press: Oxford, New York, 2005. 
643 (72) Chrysikopoulos, C. V.; Aravantinou, A. F. Virus Inactivation in the Presence of Quartz Sand 644 under Static and Dynamic Batch Conditions at Different Temperatures. J. Hazard. Mater. 2012, 233$645234,148-157$. https://doi.org/10.1016/j.jhazmat.2012.07.002.

646 (73) Pecson, B. M.; Decrey, L.; Kohn, T. Photoinactivation of Virus on Iron-Oxide Coated Sand: 647 Enhancing Inactivation in Sunlit Waters. Water Res. 2012, 46 (6), 1763-1770. 648 https://doi.org/10.1016/j.watres.2011.12.059.

649 (74) Totsche, K. U.; Jann, S.; Kögel-Knabner, I. Single Event-Driven Export of Polycyclic 650 Aromatic Hydrocarbons and Suspended Matter from Coal Tar-Contaminated Soil. Vadose Zone J. 651 2007, 6 (2), 233-243. https://doi.org/10.2136/vzj2006.0083.

652 (75) Worrich, A.; Wick, L. Y.; Banitz, T. Chapter Three - Ecology of Contaminant 653 Biotransformation in the Mycosphere: Role of Transport Processes. In Advances in Applied 654 Microbiology; Gadd, G. M., Sariaslani, S., Eds.; Academic Press, 2018; Vol. 104, pp 93-133. 655 https://doi.org/10.1016/bs.aambs.2018.05.005.

656 (76) Fester, T.; Giebler, J.; Wick, L. Y.; Schlosser, D.; Kästner, M. Plant-microbe Interactions as 657 Drivers of Ecosystem Functions Relevant for the Biodegradation of Organic Contaminants. Curr. 658 Opin. Biotechnol. 2014, 27, 168-175. https://doi.org/10.1016/j.copbio.2014.01.017.

659 (77) Otten, W.; Hall, D.; Harris, K.; Ritz, K.; Young, I. M.; Gilligan, C. A. Soil Physics, Fungal 660 Epidemiology and the Spread of Rhizoctonia Solani. New Phytol. 2001, 151 (2), 459-468. 661 https://doi.org/10.1046/j.0028-646x.2001.00190.x.

662 (78) Williamson, K. E.; Radosevich, M.; Wommack, K. E. Abundance and Diversity of Viruses in 663 Six Delaware Soils. Appl. Environ. Microbiol. 2005, 71 (6), 3119-3125. 664 https://doi.org/10.1128/AEM.71.6.3119-3125.2005.

665 (79) Narr, A.; Nawaz, A.; Wick, L. Y.; Harms, H.; Chatzinotas, A. Soil Viral Communities Vary 666 Temporally and along a Land Use Transect as Revealed by Virus-Like Particle Counting and a 667 Modified Community Fingerprinting Approach (FRAPD). Front. Microbiol. 2017, 8. 668 https://doi.org/10.3389/fmicb.2017.01975.

669 (80) Sirivithayapakorn, S.; Keller, A. Transport of Colloids in Saturated Porous Media: A Pore670 Scale Observation of the Size Exclusion Effect and Colloid Acceleration. Water Resour. Res. 2003, 39 671 (4), n/a-n/a. https://doi.org/10.1029/2002WR001583.

672 (81) Worrich, A.; Wick, L. Y.; Banitz, T. Ecology of Contaminant Biotransformation in the 673 Mycosphere: Role of Transport Processes. Adv. Appl. Microbiol. 2018, 104, 93-133. 674 https://doi.org/10.1016/bs.aambs.2018.05.005.

675 (82) Pratama, A. A. and van Elsas J. D.; Gene mobility in microbiomes of the mycosphere and 676 mycorrhizosphere -role of plasmids and bacteriophages. FEMS Microbiol. Ecol. 2019, 95, Issue 5, 677 fiz053, https://doi.org/10.1093/femsec/fiz053. 
681
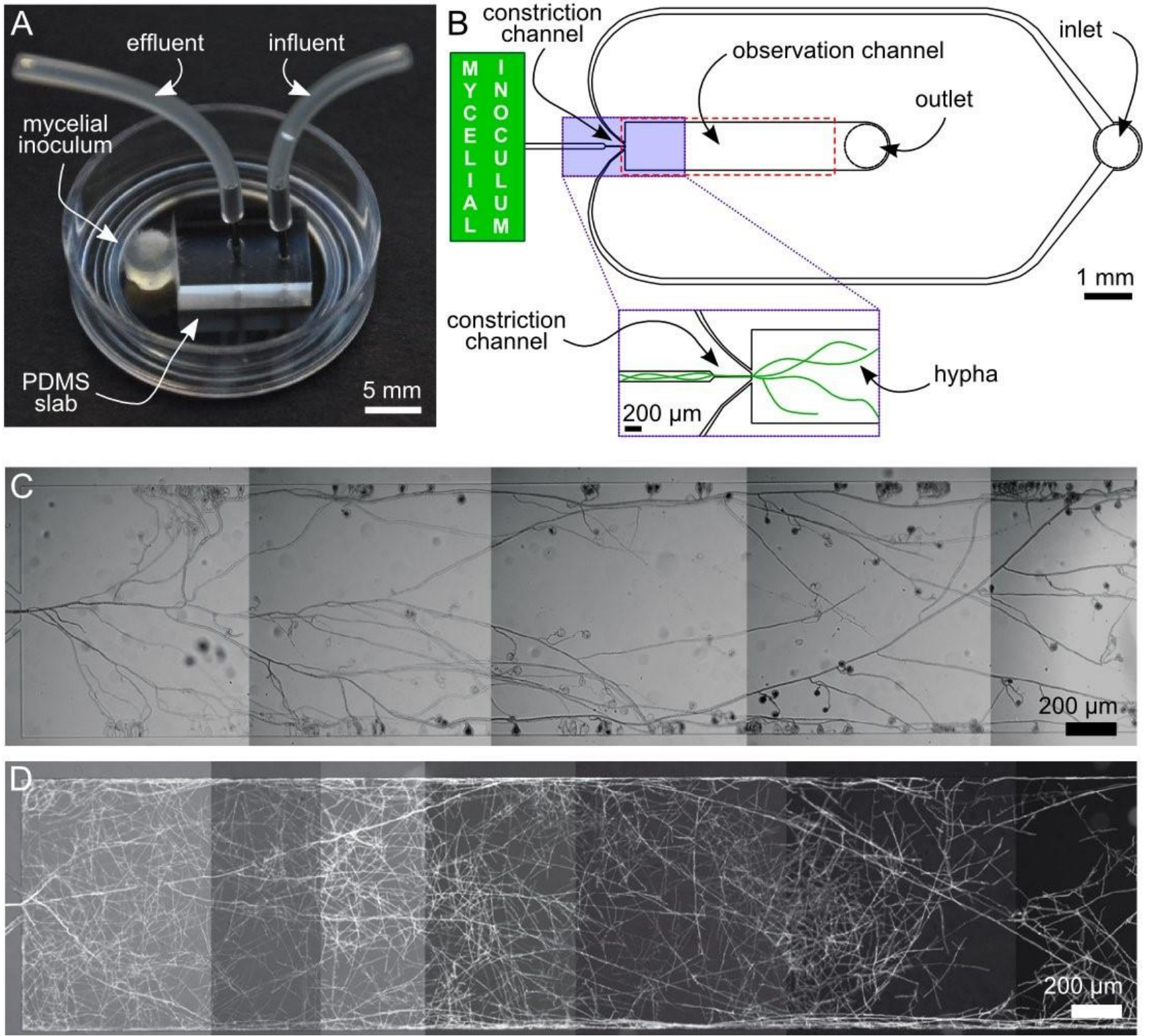

Figure 1 
691
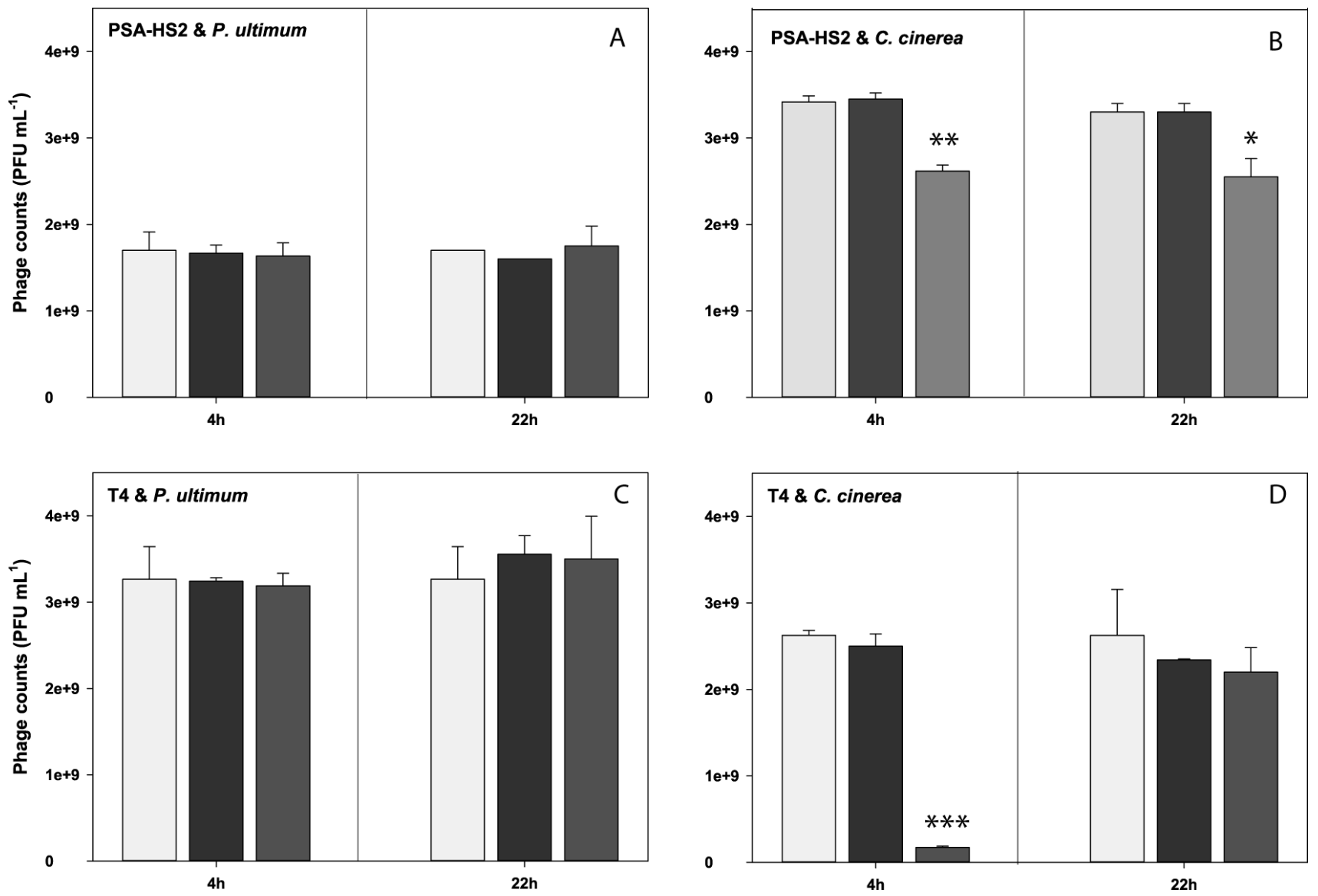

692

Figure 2

694

695

696

697

698

699

700

701

702 


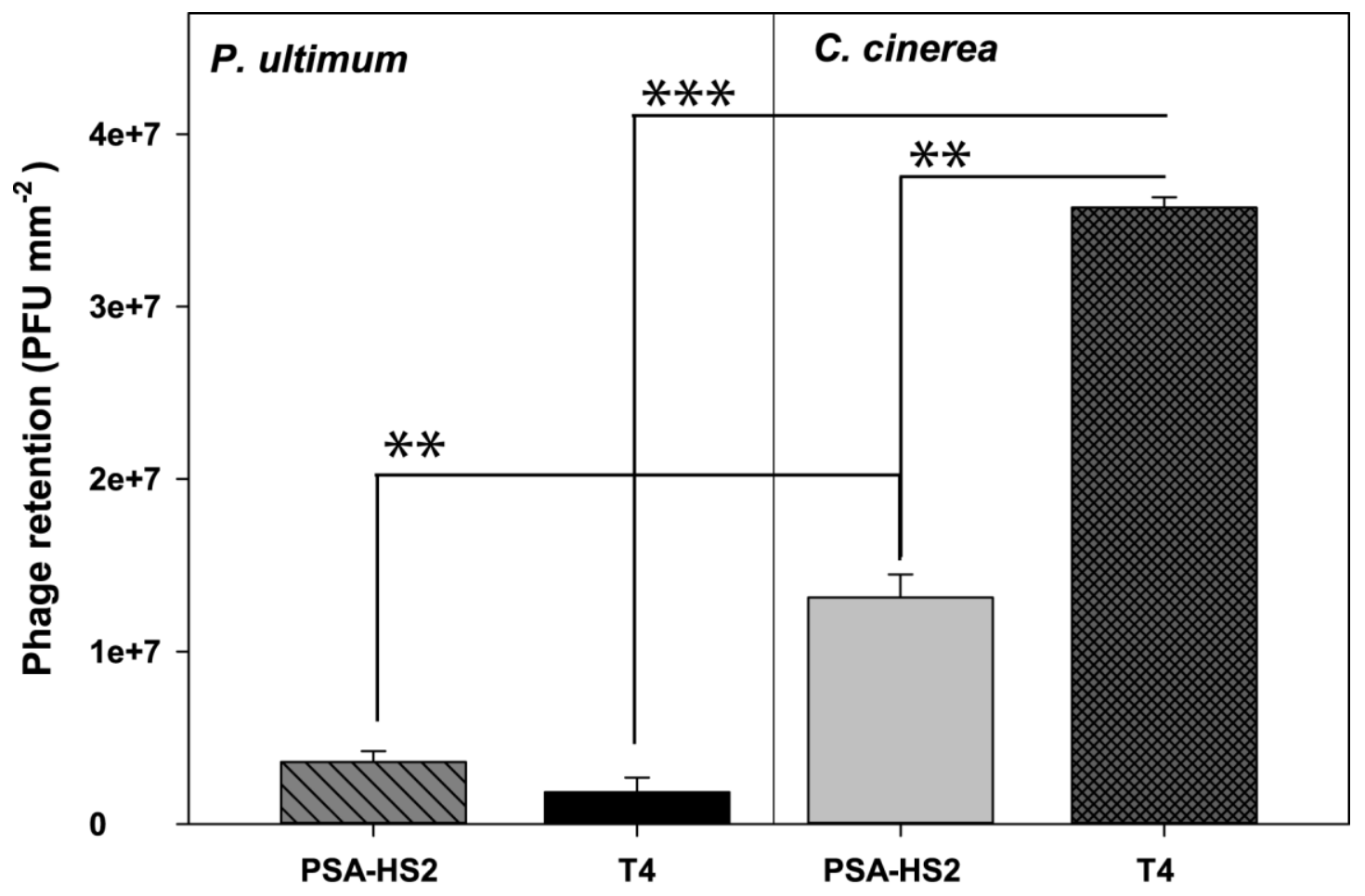

703

Phage

$704 \quad$ Figure 3

705

706

707

708

709

710

711 

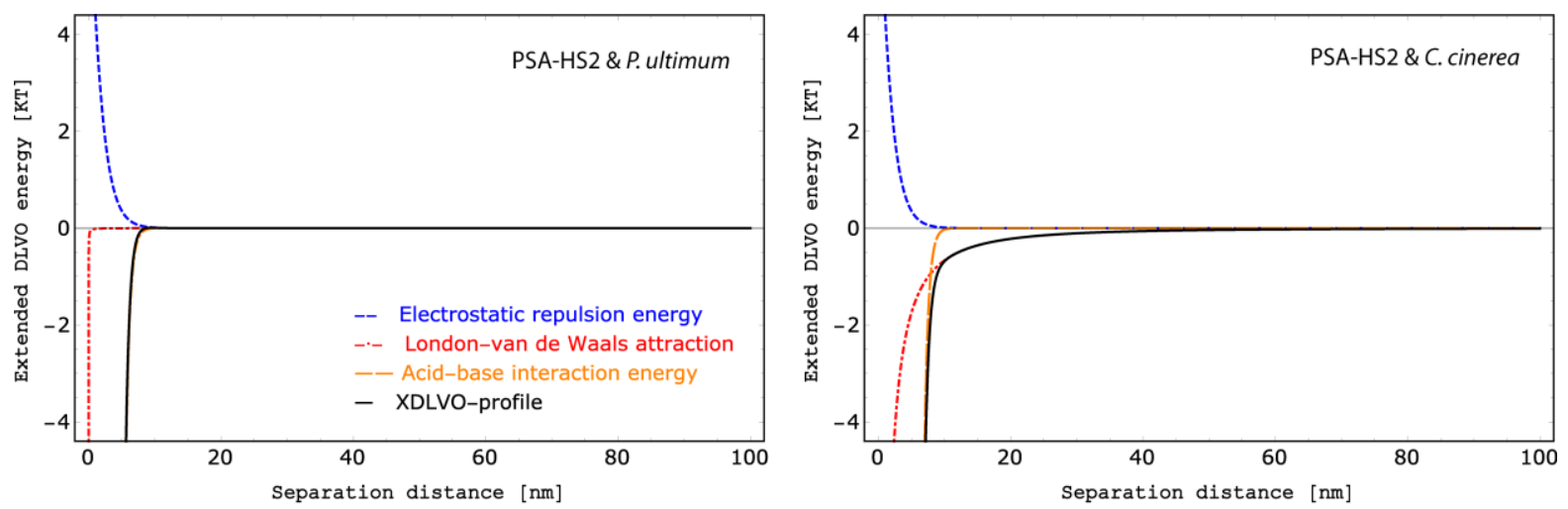

712
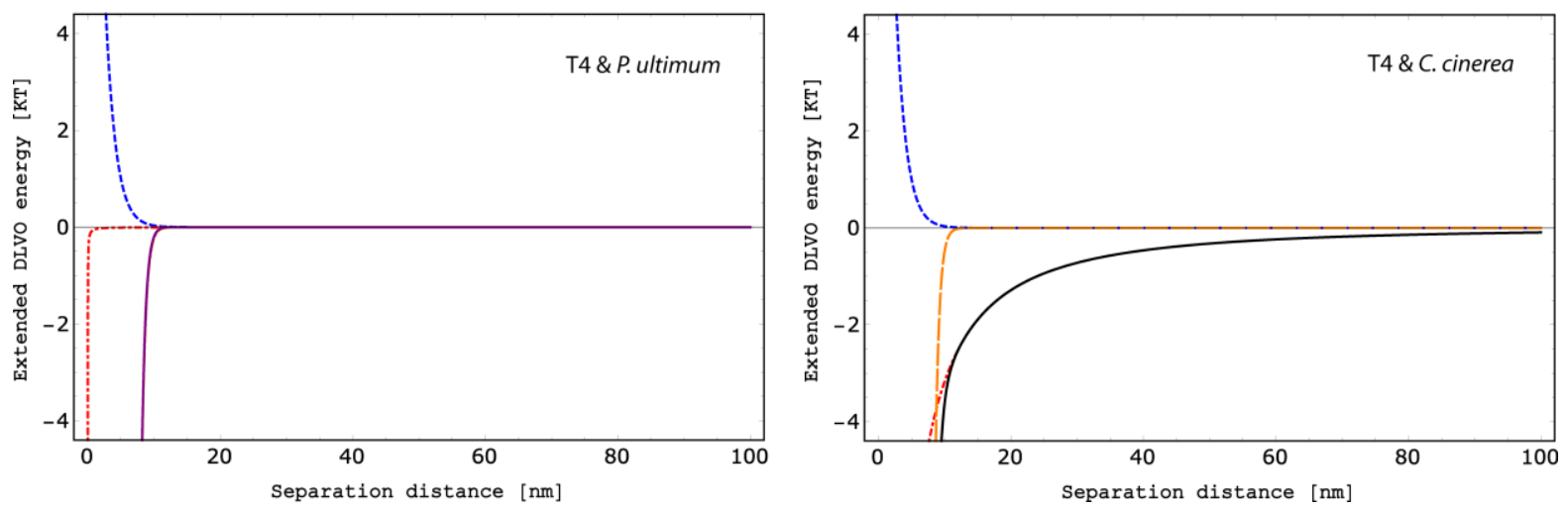

713

\section{$714 \quad$ Figure 4}

715

716 
Supporting information

\section{Mycelial Effects on Phage Retention During Transport in a Microfluidic Platform}

Nawras Ghanem ${ }^{1}$, Claire E. Stanley ${ }^{2}$, Hauke Harms ${ }^{1,3}$, Antonis Chatzinotas ${ }^{1,3}$ and Lukas Y. Wick $^{1 *}$

${ }^{1}$ Helmholtz Centre for Environmental Research - UFZ, Department of Environmental Microbiology, Permoserstraße 15, 04318 Leipzig, Germany.

${ }^{2}$ Agroecology and Environment Research Division, Agroscope, Reckenholzstrasse 191, 8046 Zurich, Switzerland

${ }^{3}$ German Centre for Integrative Biodiversity Research (iDiv) Halle-Jena-Leipzig, Deutscher Platz 5e, 04103 Leipzig, Germany

Number of pages: $\quad 14$

Number of figures: $\quad 2$

Number of tables: $\quad 2$

* Corresponding author: Mailing address: Helmholtz Centre for Environmental Research - UFZ. Department of Environmental Microbiology; Permoserstrasse 15; 04318 Leipzig, Germany. phone: +49 341235 1316, fax: +49 34123545 1316, e-mail: lukas.wick@ufz.de. 


\section{MICROFLUIDIC DEVICE DESIGN AND PREPARATION}

Microfluidic devices were prepared as described in Stanley et al. ${ }^{1}$ In brief: A polyester film photolithography mask (Micro Lithography Services Ltd., UK) and a $100 \mathrm{~mm}$ silicon wafer (Silicon Materials, Germany), spin-coated with a $10 \mu \mathrm{m}$ thick layer of SU-8 photoresist (MicroChem, USA), were used to create the master mold. The channel architecture was based on the fluid exchange device, detailed in Stanley et al., ${ }^{2}$ and enables active pumping of solutions into the observation chamber (Fig. 1). Two versions of the design were made, one that allows a mycelium to occupy the observation chamber and one that does not (Fig. S3). The latter design enables control measurements to be performed (i.e., in the absence of a mycelium). Polydimethylsiloxane (PDMS) silicone elastomer was then prepared and poured onto the master mold. PDMS was prepared using a 10:1 ratio of base to curing agent (Sylgard 184, Dow Corning, USA) that was mixed thoroughly and degassed prior to pouring. After curing overnight at $70{ }^{\circ} \mathrm{C}$, the PDMS was removed from the mold and diced into slabs. A precision cutter (Syneo, USA), having a cutting edge diameter of $1.02 \mathrm{~mm}$, was used to punch the holes for the medium inlet and outlet as illustrated in Fig. 1 and Fig. S3. The PDMS slabs were washed in $0.5 \mathrm{M}$ sodium hydroxide, $70 \%$ v/v ethanol, and sterile double distilled water (ddH2O) and then dried at $70{ }^{\circ} \mathrm{C}$ for $1 \mathrm{~h}$. They were then bonded to glass-bottomed Petri dishes (World Precision Instruments) and sterilized for 20 minutes under ultraviolet light.

Fluorinated ethylene polymer (FEP) tubing (inner diameter: $0.80 \mathrm{~mm}$, outer diameter: $1.60 \mathrm{~mm}$; Cole-Parmer, Germany), hollow steel pin connectors (20 ga; Instech Laboratories, USA) and connector pins fitted with a luer-lock adaptor (20 ga; Instech Laboratories, USA) were used to connect the syringe to the microfluidic device and subsequently allow a variety of test solutions to be introduced into the observation channel (in the presence or absence of a mycelium). Fig. 1 shows an overview of the microfluidic setup for clarity.

\section{MICROFLUIDIC DEVICE: CHARACTERIZATION OF FLOW CONDITIONS}

The microfluidic device (channel height: $10 \mu \mathrm{m}$; channel width: $1000 \mu \mathrm{m}$; channel length: $6 \mathrm{~mm}$ ) operates at laminar flow conditions (i.e. is a laminar flow reactor) with a Reynold's number $(R e)$ equal to ca. 0.003 (eq. S1).

$R e=\frac{Q D_{H}}{v A}=\frac{1.4 \times 10^{-12} \mathrm{~m}^{3} / \mathrm{s} \times 2 \times 10^{-5} \mathrm{~m}}{1 \times 10^{-6} \mathrm{~m}^{2} / \mathrm{s} \times 1 \times 10^{-8} \mathrm{~m}^{2}}=\frac{2.8 \times 10^{-17} \mathrm{~m}^{4} / \mathrm{s}}{1.0 \times 10^{-14} \mathrm{~m}^{4} / \mathrm{s}}=0.003$

where:

$Q=$ volumetric flow rate $\left(\mathrm{m}^{3} / \mathrm{s}\right)$; i.e.: $Q=5 \mu \mathrm{L} \mathrm{h}^{-1}=5 \times 10^{-6} \mathrm{~L} \mathrm{~h}^{-1}=1.4 \times 10^{-12}\left(\mathrm{~m}^{3} \mathrm{~s}^{-1}\right)$

$D_{H}=$ hydraulic diameter $(\mathrm{m}), D_{H}=\frac{4 \times \text { cross sectional area }}{\text { wetted perimeter }}=\frac{4 \times 10000}{2020} \frac{\mu \mathrm{m}^{2}}{\mu \mathrm{m}}=20 \mu \mathrm{m}=2 \times 10^{-5} \mathrm{~m}$

$V=$ kinematic viscosity $\left(\mathrm{m}^{2} / \mathrm{s}\right)$; i.e. $1.0 \times 10^{-6} \mathrm{~m}^{2} / \mathrm{s}$ (for water)

$A=$ cross sectional area $\left(\mathrm{m}^{2}\right)$; i.e. $10,000 \mu \mathrm{m}^{2}=1.0 \times 10^{-8} \mathrm{~m}^{2}$ 
A syringe pump ensured that the volumetric flow rate in the microchannels is controlled by adjusting the pressure needed to produce the required flow rate independent of channel geometry. ${ }^{3}$ As the microchannels within this microfluidic device have a rectangular profile (with a high width: height ratio, i.e. $1000 / 10=100$ ), the velocity distribution profile across the microchannel is highly uniform. ${ }^{4}$

Hence, taking the average velocity of the system to be $1.4 \times 10^{-4} \mathrm{~m} \mathrm{~s}^{-1}$ (average velocity $=$ volumetric flow rate / cross section area), we estimate that it would take ca. 43 seconds for the fluid to reach the outflow (i.e. to traverse the entire observation chamber) assuming a channel length of $6 \times 10^{-3} \mathrm{~m}$.

\section{CALCULATION OF THE XDLVO INTERACTION ENERGIES OF PHAGE DEPOSITION}

The phage-mycelia interaction energy $\left(G_{\text {XDLVO }}(h)\right)$ at a distance $h(\mathrm{~nm})$ between two surfaces was calculated using the extended DLVO (XDLVO) theory (cf. eq. S2) based on the sphere-plate model. ${ }^{5}$ The XDLVO theory thereby is an extension of the DLVO approach, which is the sum of $G_{\mathrm{EDL}}, G_{\mathrm{LW}}$ and the Born repulsion energy $G_{\mathrm{Born}}$. In the XDLVO theory, the energy $G_{\mathrm{XDLVO}}(h)$ is composed of the electrostatic repulsion $\left(G_{\mathrm{EDL}}\right)$, the Lifshitz-van der Waals $\left(G_{\mathrm{LW}}\right)^{6}$ and the acid-base $\left(\mathrm{G}_{\mathrm{AB}}\right)$ interaction energy (eq. S2). ${ }^{5}$

$$
G_{\mathrm{XDLVO}}(h)=G_{\mathrm{AB}}+G_{\mathrm{EDL}}(h)+G_{\mathrm{LW}}(h)
$$

The DLVO approach does not consider the polar forces that are supposed to be dominant forces between particles in polar media. ${ }^{7}$ Additionally, the acid-base $\left(G_{\mathrm{AB}}\right)$ interaction energy was reported in many studies to be essential in explaining the interaction behavior between approached particles. ${ }^{5,8}$

\section{Acid-base interaction energy $\left(G_{\mathrm{AB}}\right)$}

Eq. S3 was applied to calculate the acid-base interaction energy $\left(G_{\mathrm{AB}}\right):^{9,5}$

$G_{A B}(h)=2 \pi a_{P} \Delta G^{A B} \lambda \exp \left(\frac{l_{0}-h}{\lambda}\right)$

Where $a_{P}$ is the radius of phages, and $h$ is the separation distance between the phage and the mycelial surface. The $\lambda$ is the characteristic decay length of $A B$ interaction in water (estimated to be $0.6 \mathrm{~nm}$ ). ${ }^{10}$ The acid-base interaction energy depends on the Gibbs free energy of the phage and the fungus as given by eq. S3. $\Delta G^{\mathrm{AB}}$ is the acid-base component of the free energy interaction at contact given by eq. $\mathrm{S} 4:^{10,7}$

$$
\begin{aligned}
& \Delta G^{A B}=\left[2\left(\sqrt{\gamma_{P}^{+}}-\sqrt{\gamma_{F}^{+}}\right)\left(\sqrt{\gamma_{P}^{-}}-\sqrt{\gamma_{F}^{-}}\right)-\left(\sqrt{\gamma_{P}^{+}}-\sqrt{\gamma_{l}^{+}}\right)\left(\sqrt{\gamma_{P}^{-}}-\sqrt{\gamma_{l}^{-}}\right)-\left(\sqrt{\gamma_{F}^{+}}-\right.\right. \\
& \left.\left.\sqrt{\gamma_{\mathrm{l}}^{+}}\right)\left(\sqrt{\gamma_{F}^{-}}-\sqrt{\gamma_{\mathrm{L}}^{-}}\right)\right]
\end{aligned}
$$


The surface Gibbs free energy of phage $\gamma_{P}$ and the fungal $\gamma_{F}$ surfaces $\left(\mathrm{mJ} \mathrm{m}^{-2}\right)$ were calculated based on the measured contact angles $(\theta)$ of phages, membrane filters and fungal surfaces using water, formamide and methylene iodide as liquids by applying the Young equation according to eq. S5:

$\cos (\theta)=-1+2 \frac{\sqrt{\gamma_{P}^{L W} \gamma_{\mathrm{l}}^{L W}}}{\gamma_{\mathrm{l}}^{\text {total }}}+2 \frac{\sqrt{\gamma_{P}^{+} \gamma_{\mathrm{l}}^{-}}}{\gamma_{\mathrm{l}}^{\text {total }}}+2 \frac{\sqrt{\gamma_{P}^{-} \gamma_{\mathrm{l}}^{+}}}{\gamma_{\mathrm{l}}^{\text {total }}}$

The total surface Gibbs free energy ( $\left.\gamma^{\text {total }}\right)$ is separated in a Lifshitz-van der Waals $\left(\gamma^{\mathrm{LW}}\right)$ and an acid-base component $\left(\gamma^{\mathrm{AB}}\right)$ and is represented by eq. S6. The electron acceptor and the electron donor components of acid-base surface energy $\gamma^{+}$and $\gamma^{-}$is shown in eq. S7.

$\gamma^{\text {total }}=\gamma^{A B}+\gamma^{L W}$

$\gamma_{i}^{A B}=2 \sqrt{\gamma_{i}^{+} \gamma_{i}^{-}}$

Following van Oss et al. ${ }^{11}$ we calculated the phage parameters $\gamma_{\mathrm{p}}, \gamma_{\mathrm{p}}{ }^{\mathrm{LW}}, \gamma_{\mathrm{p}}{ }^{+}, \gamma_{\mathrm{p}}{ }^{-}$, while literature data was utilized for water, formamide and methyleneiodide. ${ }^{12}$

\section{Electrostatic repulsion energy $\left(G_{E D L}\right)$}

Eq. S8 was applied to calculate the electrostatic repulsion energy between phages and the fungal surface: ${ }^{13}$

$G_{E D L}=\pi \varepsilon_{0} \varepsilon_{r} a_{p}\left\{2 \zeta_{p} \zeta_{F} \ln \left[\frac{1+\exp (-\kappa h)}{1-\exp (-\kappa h)}\right]+\left(\zeta_{p}^{2}+\zeta_{F}^{2}\right) \ln [1-\exp (-2 \kappa h)]\right.$

where $\kappa^{-1}$ is the thickness of the electrical double layer (EDL, nm) as calculated by the GuoyChapman theory with $C$ and $\mathrm{z}$ being the molar bulk concentration and the charge number of the electrolytes, respectively (eq. S9).

$\kappa^{-1}=\left[3.29 z C^{1 / 2}\right]^{-1}$

For a $100 \mathrm{mM}$ buffer solution a $\kappa^{-1}$ of $0.65 \mathrm{~nm}$ was calculated. ${ }^{12}$

\section{Lifshitz-van der Waals interaction energy $\left(G_{L W}\right)$}

Using the values of the effective Hamaker constant (eq. S11), the Lifshitz-van der Waals interaction energy can be approximated by eq. S10:,12

$G_{L W}=-\frac{A_{132}}{6}\left[\frac{2 a_{p}\left(h+a_{p}\right)}{h\left(h+a_{p}\right)}-\ln \left(\frac{h+2 a_{p}}{h}\right)\right]$

The Hamaker constant $\mathrm{A}_{132}$ is described by eq. S11: ${ }^{14}$

$A_{123}=\left(\sqrt{A_{11}}-\sqrt{A_{33}}\right)\left(\sqrt{A_{22}}-\sqrt{A_{33}}\right)$ 
Here, $A_{i i}$ denotes the individual Hamaker constant for phages $\left(A_{11}\right)$, hyphae $\left(A_{22}\right.$, ) and water $\left(A_{33}\right) . A_{33}$ was taken from the literature, ${ }^{14}$ while $A_{11}$ and $A_{22}$ were calculated by eq. S12.

$$
A_{i i}=6 \pi l_{0}^{2} \gamma_{i}^{L W}
$$

According to Fowkes, ${ }^{15}$ the value of $6 \pi l_{0}{ }^{2}$ equals $1.44 \times 10^{-18} \mathrm{~m}^{2}$, with $l_{0}$ being the equilibrium separation distance between the phage and the fungus $(0.157 \mathrm{~nm}){ }^{11}$ 
Table S1. Overview of the surface Gibbs free energy $(\gamma)$ and the contact angles of water $\left(\theta_{\mathrm{w}}\right)$, formamide $\left(\theta_{\mathrm{f}}\right)$ and methylene iodide $\left(\theta_{\mathrm{m}}\right)$ for the phages and hyphae studied.

\begin{tabular}{lcccccccc}
\hline Name & \multicolumn{9}{c}{ Contact angle $(\Theta)$} & \multicolumn{2}{c}{ Surface free energy $\left(\mathrm{mJ} \mathrm{m}^{-2}\right)^{\mathbf{1}}$} & & \\
& $\Theta_{w}$ & $\Theta_{f}$ & $\Theta_{m}$ & $r$ & $r^{+}$ & $r^{\mathrm{AB}}$ & $r^{\mathrm{Lw}}$ & $r^{\text {Tot }}$ \\
\hline water & - & - & - & $25.5^{*}$ & $25.50^{*}$ & $51.0^{*}$ & $21.8^{*}$ & $72.8^{*}$ \\
formamide & - & - & - & $39.6^{*}$ & $2.30^{*}$ & $19.0^{*}$ & $39.0^{*}$ & $58.0^{*}$ \\
methylene iodide & - & - & - & $<0.1^{*}$ & $<0.1^{*}$ & $\approx 0^{*}$ & $50.8^{*}$ & $50.8^{*}$ \\
membrane filter Anodisc 25 & 23 & - & - & - & - & - & - & - \\
T4 & 95 & 61 & 40 & 0.1 & 0.30 & 0.2 & 39.5 & 39.7 \\
PSA-HS2 & 40 & 31 & 43 & 34.6 & 0.96 & 11.5 & 38.0 & 49.5 \\
Pythium ultimum & 62 & 47 & 72 & 17.3 & 4.49 & 17.6 & 21.8 & 39.4 \\
Coprinopsis cinerea & 131 & 106 & 131 & 0.0 & 4.47 & 0.2 & 1.5 & 1.7 \\
\hline
\end{tabular}

${ }^{*}$ Surface free energy data for water, formamide and methylene iodide taken from. ${ }^{12}$ 
Table S2. Composition of the YMG and CCMM media use for C. cinerea. $^{1}$

\begin{tabular}{|l|l|}
\hline Medium & Composition \\
\hline Yeast-malt extract-glucose (YMG) medium & $\begin{array}{l}0.4 \% \mathrm{w} / \mathrm{v} \text { yeast extract, } 1 \% \mathrm{w} / \mathrm{v} \text { malt extract, } 0.4 \% \\
\mathrm{w} / \mathrm{v} \text { glucose, } 1.5 \% \mathrm{w} / \mathrm{v} \text { agar }\end{array}$ \\
\hline C. cinerea minimal medium (CCMM) & $\begin{array}{l}5 \mathrm{~g} \mathrm{~L}^{-1} \text { glucose, } 2 \mathrm{~g} \mathrm{~L}^{-1} \text { asparagine, } 50 \mathrm{mg} \mathrm{L}^{-1} \text { adenine } \\
\text { sulfate, } 1 \mathrm{~g} \mathrm{~L}^{-1} \mathrm{KH}_{2} \mathrm{PO}_{4}, 2.25 \mathrm{~g} \mathrm{~L}^{-1} \mathrm{Na}_{2} \mathrm{HPO}_{4}, 0.29 \mathrm{~g} \mathrm{~L}^{-1} \\
\mathrm{Na}_{2} \mathrm{SO}_{4}, 0.5 \mathrm{~g} \mathrm{~L}^{-1} 2 \text { di-ammonium tartrate, } 0.04 \mathrm{mg} \mathrm{L}^{-1} \\
\text { thiamine hydrochloride, } 0.25 \mathrm{~g} \mathrm{~L}^{-1} \mathrm{MgSO}_{4}, \\
5 \mathrm{mg} \mathrm{L}^{-1} p \text {-aminobenzoic acid (pABA). }\end{array}$ \\
\hline
\end{tabular}




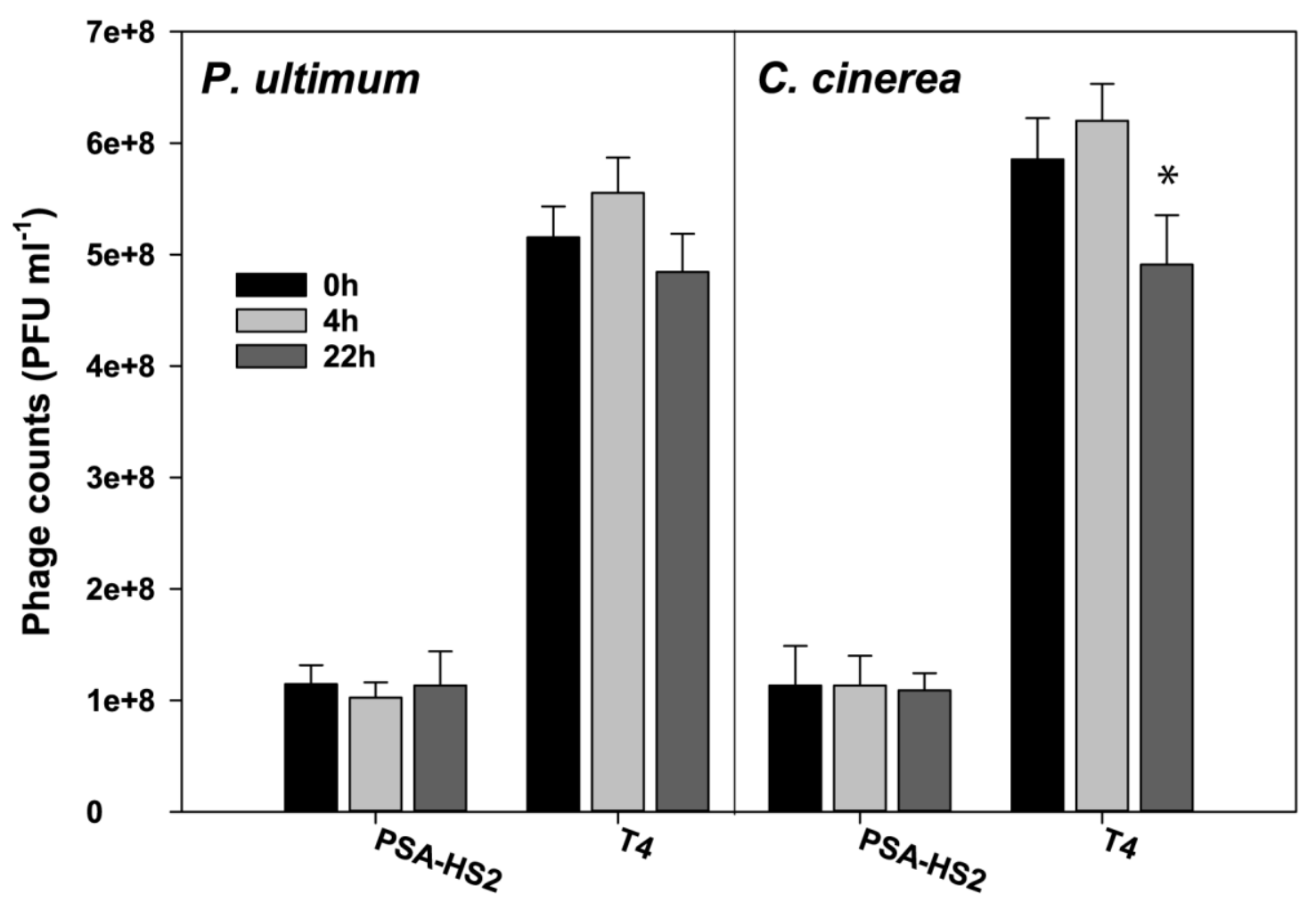

\section{Phage}

Figure S1. Stability and viability of the PSA-HS2 and T4 phage suspensions after exposure to $P$. ultimum and $C$. cinerea conditioned media (at $t=0,4$ and $22 \mathrm{~h}$ ). The results represent the average and standard deviations of triplicate experiments using phage quantification by PFU. T4 counts in the presence of $C$. cinerea conditioned medium at $t=22 \mathrm{~h}$ were statistically different to initial concentrations at $t=0$ and $t=4 \mathrm{~h}$, as indicated by the asterisk $(\mathrm{p} \leq 0.05)$. 


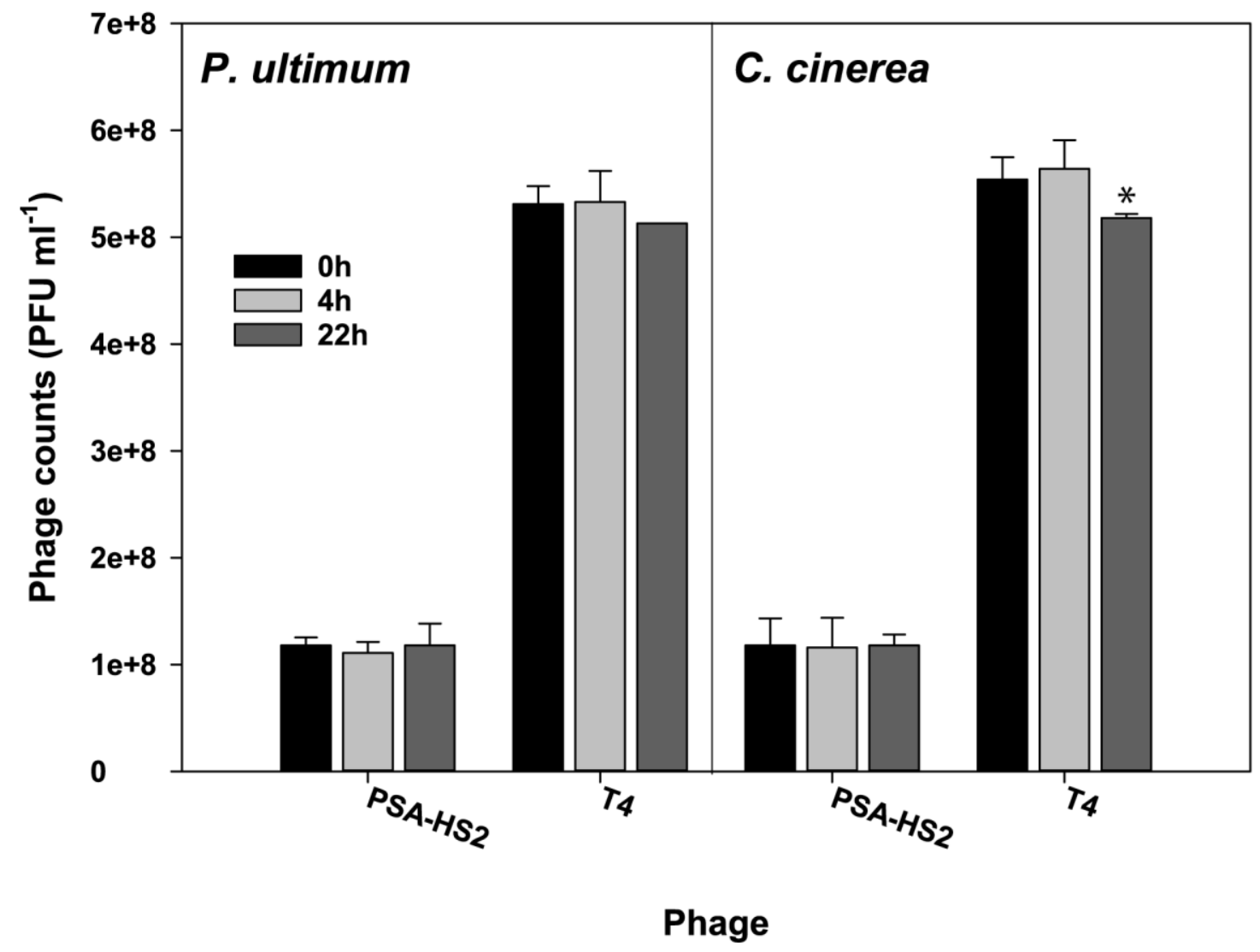

Figure S2. Stability and viability of the PSA-HS2 and T4 phage suspensions after exposure to fresh media i.e. LB and CCMM media for P. ultimum and C. cinerea, respectively at $t=0,4$ and $22 \mathrm{~h}$. The results represent the average and standard deviations of triplicate experiments using phage quantification by PFU. T4 counts in the presence of $C$. cinerea conditioned medium at $t=22 \mathrm{~h}$ were statistically different to initial concentrations at $t=0$ and $t=4 \mathrm{~h}$, as indicated by the asterisk ( $\mathrm{p} \leq$ $0.05)$. 
A

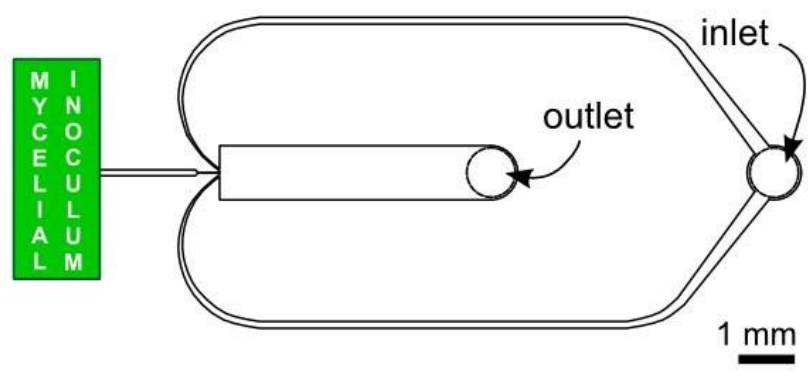

+ mycelial inoculum
B

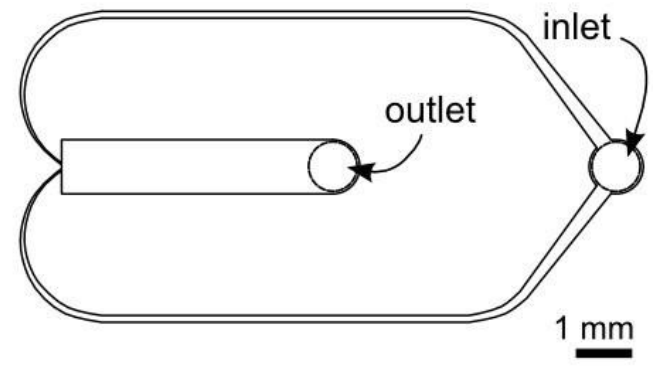

- mycelial inoculum

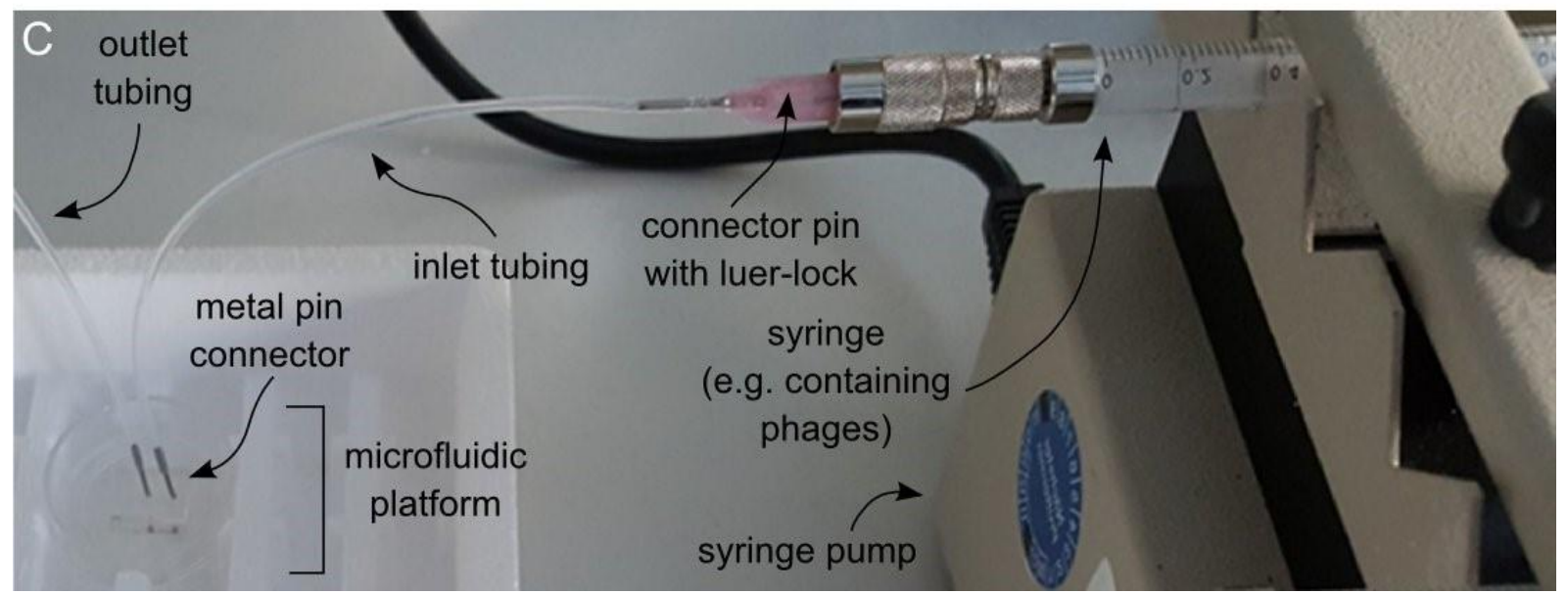

Figure S3. Design and operation of the experimental setup. (A) Two-dimensional representation of the microfluidic platform with a mycelial inoculum that was placed next to the lateral opening of the microfluidic device, allowing hyphae to penetrate and grow into the observation channel via a constriction channel. (B) Two-dimensional representation of the microfluidic platform that enables control measurements to be performed (i.e. in the absence of a mycelium). (C) Photograph illustrating the experimental setup, where a syringe pump was used to drive phage suspensions into the microfluidic channels in the presence and absence of mycelia. 


\section{REFERENCES}

(1) Stanley, C. E.; Stöckli, M.; Swaay, D. van; Sabotič, J.; Kallio, P. T.; Künzler, M.; deMello, A. J.; Aebi, M. Probing Bacterial-fungal Interactions at the Single Cell Level. Integr. Biol. 2014, 6 (10), 935-945. https://doi.org/10.1039/C4IB00154K.

(2) Stanley, C.; Shrivastava, J.; Brugman, R.; Heinzelmann, E.; Frajs, V.; Bühler, A.; van Swaay, D.; Grossmann, G. Fabrication and Use of the Dual-Flow-RootChip for the Imaging of Arabidopsis Roots in Asymmetric Microenvironments. BIO-PROTOCOL 2018, 8 (18). https://doi.org/10.21769/BioProtoc.3010.

(3) Mavrogiannis, N.; Ibo, M.; Fu, X.; Crivellari, F.; Gagnon, Z. Microfluidics Made Easy: A Robust Low-Cost Constant Pressure Flow Controller for Engineers and Cell Biologists. Biomicrofluidics 2016, 10 (3). https://doi.org/10.1063/1.4950753.

(4) Stone, H. A. Introduction to Fluid Dynamics for Microfluidic Flows. In CMOS Biotechnology; Lee, H., Westervelt, R. M., Ham, D., Eds.; Series on Integrated Circuits and Systems; Springer US: Boston, MA, 2007; pp 5-30. https://doi.org/10.1007/978-0387-68913-5_2.

(5) Chrysikopoulos, C. V.; Syngouna, V. I. Attachment of Bacteriophages MS2 and X174 onto Kaolinite and Montmorillonite: Extended-DLVO Interactions. Colloids and Surfaces B: Biointerfaces 2012, 92, 74-83. https://doi.org/10.1016/j.colsurfb.2011.11.028.

(6) Hermansson, M. The DLVO Theory in Microbial Adhesion. Colloids and Surfaces B: Biointerfaces 1999, 14 (1), 105-119.

(7) Van Oss, C. J.; Giese, R. F.; Costanzo, P. M. DLVO and Non-DLVO Interactions in Hectorite. Clays Clay Miner 1990, 38 (2), 151-159.

(8) Attinti, R.; Wei, J.; Kniel, K.; Sims, J. T.; Jin, Y. Virus' (MS2, ФX174, and Aichi) Attachment on Sand Measured by Atomic Force Microscopy and Their Transport through Sand Columns. Environmental Science \& Technology 2010, 44 (7), 2426-2432. https://doi.org/10.1021/es903221p.

(9) Tadros, T. Interfacial Forces in Aqueous Media, Carel J. van Oss, Marcel Dekker Inc., New York, 1994. J. Chem. Technol. Biotechnol. 1995, 64 (3), 311-311. https://doi.org/10.1002/jctb.280640321.

(10) van Oss, C. J.; Docoslis, A.; Wu, W.; Giese, R. F. Influence of Macroscopic and Microscopic Interactions on Kinetic Rate Constants: I. Role of the Extended DLVO Theory in Determining the Kinetic Adsorption Constant of Proteins in Aqueous Media, Using von Smoluchowski's Approach. Colloids and Surfaces B: Biointerfaces 1999, 14 (1-4), 99-104. https://doi.org/10.1016/S0927-7765(99)00028-4.

(11) Van Oss, C. J.; Chaudhury, M. K.; Good, R. J. Interfacial Lifshitz-van Der Waals and Polar Interactions in Macroscopic Systems. Chemical Reviews 1988, 88 (6), 927-941.

(12) Sharma, P. K.; Hanumantha Rao, K. Adhesion of Paenibacillus Polymyxa on Chalcopyrite and Pyrite: Surface Thermodynamics and Extended DLVO Theory. Colloids and Surfaces B: Biointerfaces 2003, 29 (1), 21-38. https://doi.org/10.1016/S0927-7765(02)00180-7.

(13) Boks, N. P.; Norde, W.; van der Mei, H. C.; Busscher, H. J. Forces Involved in Bacterial Adhesion to Hydrophilic and Hydrophobic Surfaces. Microbiology 2008, 154 (10), 3122 3133. https://doi.org/10.1099/mic.0.2008/018622-0.

(14) Van Oss, C. J.; Good, R. J.; Chaudhury, M. K. The Role of van Der Waals Forces and Hydrogen Bonds in "Hydrophobic Interactions" between Biopolymers and Low Energy Surfaces. Journal of Colloid and Interface Science 1986, 111 (2), 378-390. https://doi.org/10.1016/0021-9797(86)90041-X. 
(15) Fowkes, F. M. Attractive Forces at Interfaces. Industrial \& Engineering Chemistry 1964, $56(12), 40-52$. 